\title{
A model to assess tephra clean-up requirements in urban environments
}

\author{
Josh Hayes ${ }^{* *}$, Thomas M. Wilson ${ }^{1}$, Natalia I. Deligne ${ }^{2}$, Jim Cole ${ }^{1}$ and Matthew Hughes ${ }^{1,3}$
}

\begin{abstract}
Tephra falls can cause a range of impacts to communities by disrupting, contaminating and damaging buildings and infrastructure systems, as well as posing a potential health hazard. Coordinated clean-up operations minimise the impacts of tephra on social and economic activities. However, global experience suggests clean-up operations are one of the most challenging aspects of responding to and recovering from tephra falls in urban environments. Here, we present a method for modelling coordinated municipal-led (town/district level authorities) tephra clean-up operations to support pre-event response and recovery planning. The model estimates the volume of tephra to be removed, clean-up duration, and direct costs. The underpinning component of the model is a scalable clean-up response framework, which identifies and progressively includes more urban surfaces (e.g., roofs, and roads) requiring clean-up with increasing tephra thickness.

To demonstrate model applicability, we present four clean-up scenarios for the city of Auckland, New Zealand: $1 \mathrm{~mm}$ and $10 \mathrm{~mm}$ distal tephra fall across the city, along with two local 'wet' eruption scenarios (low and high volume tephra deposition) from within the Auckland Volcanic Field. Depending on the modelled scenario, outputs suggest that coordinated clean-up operations in Auckland could require the removal of tens of thousands to millions of cubic metres of tephra. The cost of these operations are estimated to be NZ\$0.6-1.1 million (US\$0.4-0.7 million) for the $1 \mathrm{~mm}$ distal tephra scenario and NZ\$13.4-25.6 million (US\$9-17 million) for the $10 \mathrm{~mm}$ distal tephra scenario. Estimated clean-up costs of local eruptions range from tens of millions to hundreds of millions of dollars. All eruption scenarios indicate clean-up operations lasting weeks to months, but clean-up in some areas impacted by local eruptions could last for years. The model outputs are consistent with documented historic tephra clean-up operations. Although we use Auckland as a proof-of-concept example, the method may be adapted for any city exposed to a tephra hazard.
\end{abstract}

Keywords: Hazard, Risk, Volcanic ash, Waste, Disaster, Recovery, Response, Planning, Auckland, New Zealand, Auckland Volcanic Field

\section{Introduction}

Disaster waste products such as construction and demolition debris, hazardous chemicals (e.g., pesticides and cleaning agents), and unconsolidated material from natural hazard processes (e.g., liquefaction ejecta, flood silt, landslide debris, and tephra) are contributors to the negative impacts of disasters because they hinder emergency response and urban recovery efforts (Kobayashi 1995; Brown et al. 2011a). In particular, unconsolidated material from natural hazards can cover large areas and cause

\footnotetext{
* Correspondence: josh.hayes911@gmail.com

${ }^{1}$ Department of Geological Sciences, University of Canterbury, Christchurch, New Zealand

Full list of author information is available at the end of the article
}

considerable disruption to transportation, water supply, wastewater, and electricity networks (Blong 1984; Harp and Jibson 1996; Villemure et al. 2012; Wilson et al. 2012; Howes and Cheesebrough 2013; Comes and Van De Walle 2014; Wilson et al. 2014; Hayes et al. 2015). For example, volcanic ash from the 2011 Cordón-Caulle eruption caused the closure of Bariloche airport in Argentina until clean-up was conducted Wilson et al. (2013). Further, in some situations, the presence of large quantities of unconsolidated sediment, including tephra, has led to public health hazards such as respiratory, skin, and eye irritations and infectious diseases (Young et al. 2004; Horwell and Baxter 2006; Brown et al. 2011a; Lane et al. 2013). 
Waste management after a disaster commonly consists of mobilising large clean-up workforces as part of coordinated clean-up operations to remove disaster waste from the point of generation and/or deposition to the intended site of disposal (Brown et al. 2011a). Thus, disaster waste management planning (when it is undertaken) is typically included as part of response planning conducted within the readiness phase of the disaster management framework (United States Environmental Protection Agency 2008). Best-practice planning for disaster waste includes estimating the amount of debris to be cleaned up, considering local environmental regulations, identifying disposal sites, determining the roles of stakeholders involved with clean-up activities, determining manual labour and machinery resource requirements, identifying health and safety hazards, establishing public communication protocols and funding mechanisms (United States Environmental Protection Agency 2008; Brown et al. 2011a; United Nations Office for the Coordination of Humanitarian Affairs 2011). Existing disaster waste plans have mostly focused on hazards such as flooding, extreme weather (e.g., hurricane or tornado) and earthquake-induced debris (e.g., City of Miami 2008; Johnston et al. 2009; City and County of San Francisco 2011). There are few known examples of specific planning for tephra clean-up beyond those carried out in Auckland, New Zealand (Dolan et al. 2003; Johnston et al. 2001; Magill et al. 2006) Kagoshima, Japan (Kagoshima City 2013), and a review by Hayes et al. (2015).

Explosive volcanic eruptions can deposit large volumes of tephra onto communities, requiring large-scale cleanup operations (Hayes et al. 2015). For example, over 11 million $\mathrm{m}^{3}$ of tephra were deposited on Guatemala City following the 2010 Pacaya eruption (Wardman et al. 2012). Adverse effects of tephra on communities include disruption of infrastructure networks (e.g., transportation, electricity, and water; Wilson et al. 2012; Wilson et al. 2014), public health concerns (Blong 1984; Horwell et al. 2003; Horwell and Baxter 2006; Stewart et al. 2006), and in some situations damage to buildings and property such as roof collapse (Spence et al. 2005; Jenkins et al. 2014). Tephra clean-up operations minimise or mitigate these adverse effects by removing tephra from the urban environment (Hayes et al. 2015). However, these operations can be challenging to municipal (town/district level) authorities as they require removal, transport and disposal of large volumes of tephra. Operations can be dependent on a range of context-specific factors such as level of prior planning, access to resources, involvement of citizens in clean-up operations, remobilisation potential of tephra, tephra deposit thickness, and whether rainfall entrains tephra into storm water systems (Hayes et al. 2015).

Here, we describe a tephra clean-up model that can inform municipal response and recovery planning for tephra in urban environments. Our model estimates the volume of tephra that will need to be removed under different eruption scenarios, which then allows for an assessment of the duration and cost of clean-up operations.

\section{Study overview}

We first present the conceptual steps that are required to develop a tephra clean-up model for urban environments. This includes discussion of:

- hazard scenarios required to model tephra clean-up operations;

- a conceptual framework for clean-up operation response to inform estimates of tephra removal volumes;

- local contextual information required for modelling tephra clean-up operations; and

- applying or developing appropriate equations to assess duration and cost of clean-up operations.

Following this, we describe the specific methodological steps and decisions made to customise this model for Auckland, New Zealand. We use distal and local eruption scenarios as a proof of concept, and to demonstrate how potential cost and duration of tephra cleanup operations in Auckland can yield useful information for planning purposes. Finally, we critically discuss the model and its results for the purpose of assessing usefulness, viability, adaptability, and model limitations.

\section{Study area and previous work}

Our study uses Auckland, New Zealand to demonstrate the application of our tephra clean-up model. Auckland is the most populous region in New Zealand with 1.6 million residents and accounts for 35\% of the New Zealand Gross Domestic Product (Statistics New Zealand 2013; 2015). The city is exposed to both distal and local tephra hazards (Fig. 1).

The North Island of New Zealand has at least seven volcanoes/volcanic centres whose tephra fall can impact Auckland (Fig. 1a). Lake cores within the Auckland area preserve 70 distal tephra fall deposits ranging from $0.5-$ $630 \mathrm{~mm}$ in thickness since $87 \mathrm{ka}$ (Green et al. 2014). Rhyolitic tephra deposits have been identified as sourced from the Taupo Volcanic Centre, Okataina Volcanic Centre, and Mayor Island. Andesitic tephras have been identified from Mt. Taranaki and Tongariro Volcanic Centre (Green et al. 2014).

In addition to the distal tephra exposure, the Auckland metropolitan area is built upon the monogenetic Auckland Volcanic Field (AVF; Fig. 1b). The AVF comprises over 50 volcanoes formed mainly by phreatomagmatic and/or magmatic eruption styles (Kereszturi et al. 2013; Hopkins et al. 


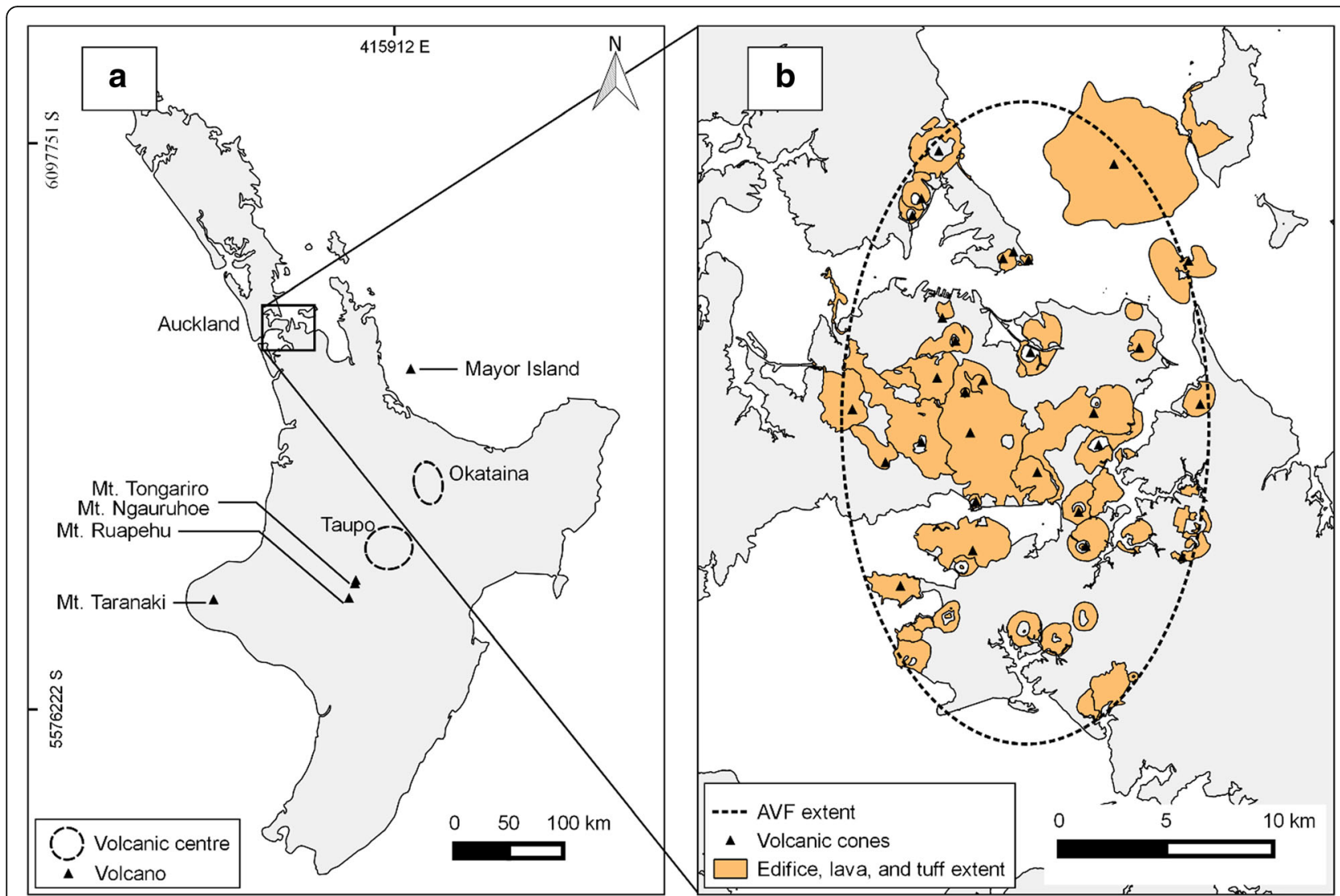

Fig. 1 a Potential sources of tephra in the vicinity of Auckland, New Zealand. b Vents and deposit extent of the Auckland Volcanic Field (AVF) (from Kermode 1992 and Runge et al. 2015)

2015). Over the last $190 \mathrm{ka}$ (G. Leonard, pers comm, 2016), the AVF has produced over $1.7 \mathrm{~km}^{3}$ of eruptive deposits (Kereszturi et al. 2013). The annual probability of an eruption within the AVF ranges from $0.03-0.08 \%$ depending on assumptions within different probabilistic hazard models (Molloy et al. 2009; Hurst and Smith 2010; Bebbington and Cronin 2011). However, activity has been clustered through time, with repose periods of $<0.5$ k.y. to 20 k.y. (Molloy et al. 2009; Hopkins et al. 2015). Probabilistic hazard models indicate that in Auckland the annual probability for $1 \mathrm{~mm}$ tephra thickness from all sources (local and distal) for $\geq$ VEI 4 eruptions is $0.9 \%$ (Jenkins et al. 2012) and for $>10 \mathrm{~mm}$ from all sources (local and distal) is approximately $0.02 \%$ (Jenkins et al. 2012) to $0.03 \%$ (Hurst and Smith 2010).

Earlier work identified potential tephra disposal sites (Fig. 2) and credible tephra volumes that would require removal in Auckland (Johnston et al. 2001; Dolan et al. 2003; Auckland Civil Defence and Emergency Management 2015). Since then, a greater understanding has been gained from investigations of global experiences of tephra cleanup operations, so it is timely to reassess these plans to determine their appropriateness in the modern Auckland context. To do this, we apply our quantitative tephra clean-up model for the Auckland metropolitan area. The model's design is informed by a review of previous urban tephra fall clean-up operations (Hayes et al. 2015). To demonstrate model utility, we take a deterministic approach by considering potential distal and local eruption scenarios affecting Auckland.

\section{Tephra clean-up model \\ Conceptual overview}

The conceptual steps and considerations required to develop a tephra clean-up model for municipal authorities are outlined in Fig. 3. The three aspects necessary to assess the tephra clean-up operations for response and recovery are: the quantity of material to collect, transport, and dispose; cost of operations; and duration of operations.

\section{Determining quantity of tephra for removal}

To determine the quantity (volume) of tephra to be removed from an urban environment following deposition, it is necessary to firstly determine the total quantity of tephra deposited in the urban area, typically using an isopach map. Secondly, the proportion of this tephra to be removed must be determined, as it is unlikely that the total volume of tephra will be completely removed (Hayes et al. 2015). 


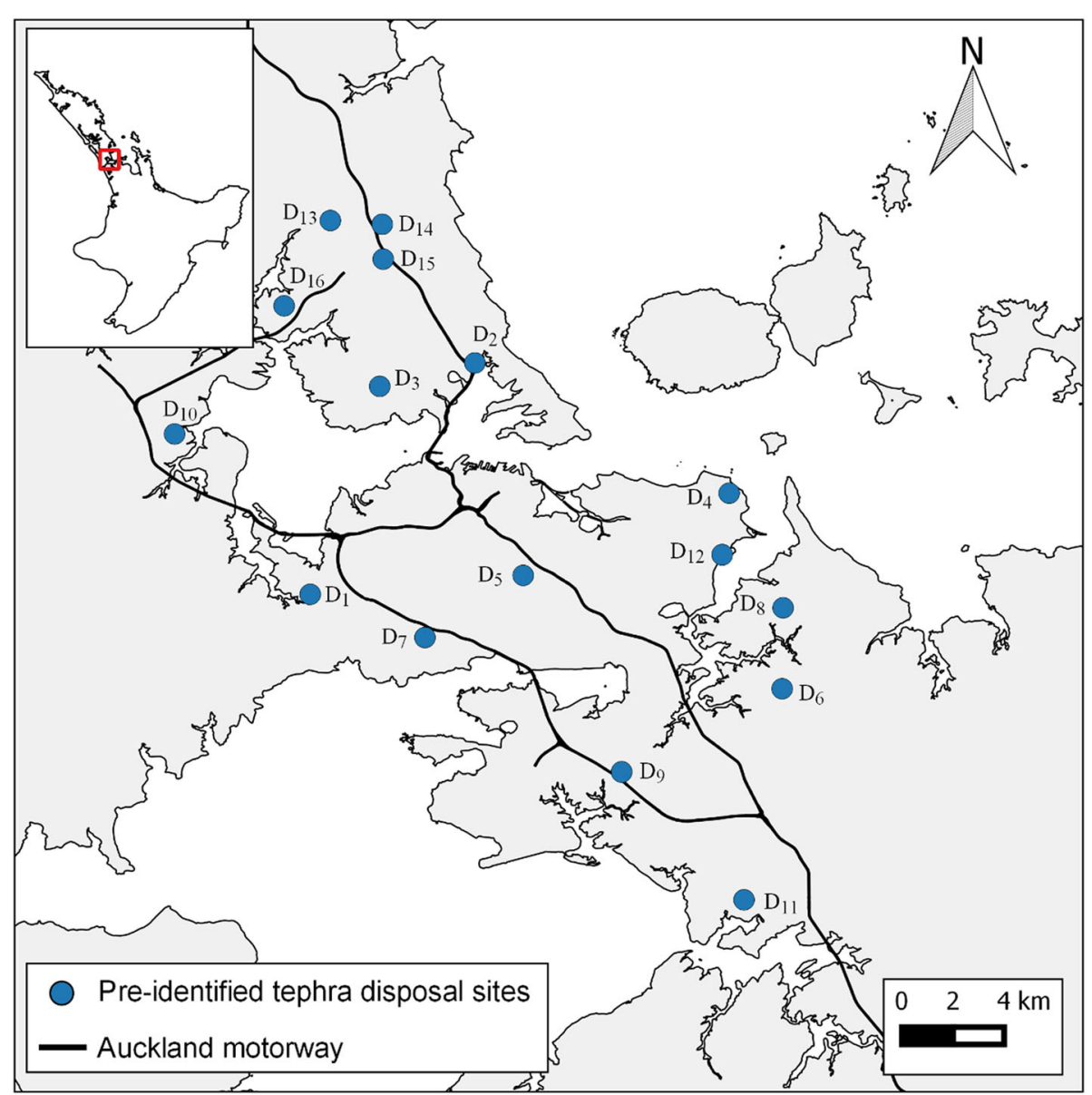

Fig. 2 Locations of pre-identified tephra disposal sites in Auckland (ACDEM 2015)

Hayes et al. (2015) compiled a catalogue of tephra clean-up operations in urban environments from around the world, which indicates an increasing proportion of a tephra deposit is removed as deposit thickness increases. Land-use of an urban area exposed to tephra deposition also influences how much tephra is collected (e.g., from a recreational park compared to a high-density commercial area). Accordingly, identifying thickness thresholds as a function of impacted land use is important to include in any tephra clean up model (Table 1). For example, mitigating impacts on transportation networks will be a primary focus when responding to a tephra fall to ensure functioning routes for evacuation and movement of responding agencies. Because road traction reductions occur at thicknesses as low as $1 \mathrm{~mm}$, and road markings are obscured at thicknesses as low as $0.5 \mathrm{~mm}$ (Blong 1984; Magill et al. 2013; Blake et al. 2016), clean-up operations on roads are often initiated at thicknesses between 0.5 and $1 \mathrm{~mm}$ (Hayes et al. 2015). In comparison, at these small thicknesses, private property owners (homes and businesses) often self-manage clean-up (Hayes et al. 2015).
Where tephra deposits are sufficiently thick and widespread, municipal/emergency management, volunteer and sometimes commercial resources are required to aid clean-up of urban areas; such concerted responses have been documented in areas impacted by $20-30 \mathrm{~mm}$ of tephra in Guatemala City (Wardman et al. 2012), 150$170 \mathrm{~mm}$ in Villa la Angostura, Argentina (Wilson et al. 2013; Craig et al. 2016), and $40 \mathrm{~mm}$ in Bariloche, Argentina (Wilson et al. 2013). Typically, a concerted response is initiated at around $10 \mathrm{~mm}$ thickness of tephra.

Clean up thresholds for urban green spaces tend to be different from residential and commercial land-uses. Data from Hayes et al. (2015) indicate that deposits $>50 \mathrm{~mm}$ in thickness need to be removed from vegetated areas, as this thickness is too great for natural incorporation into the soil within reasonable timeframes. If tephra is not removed it can lead to tephra remobilisation, inhibit use of the surface (e.g., recreation activities), and potentially kill the buried vegetation (Craig et al. 2016). Hayes et al. (2015) proposed tephra accumulation thresholds for when different clean-up responses and methods are initiated (Table 1). 


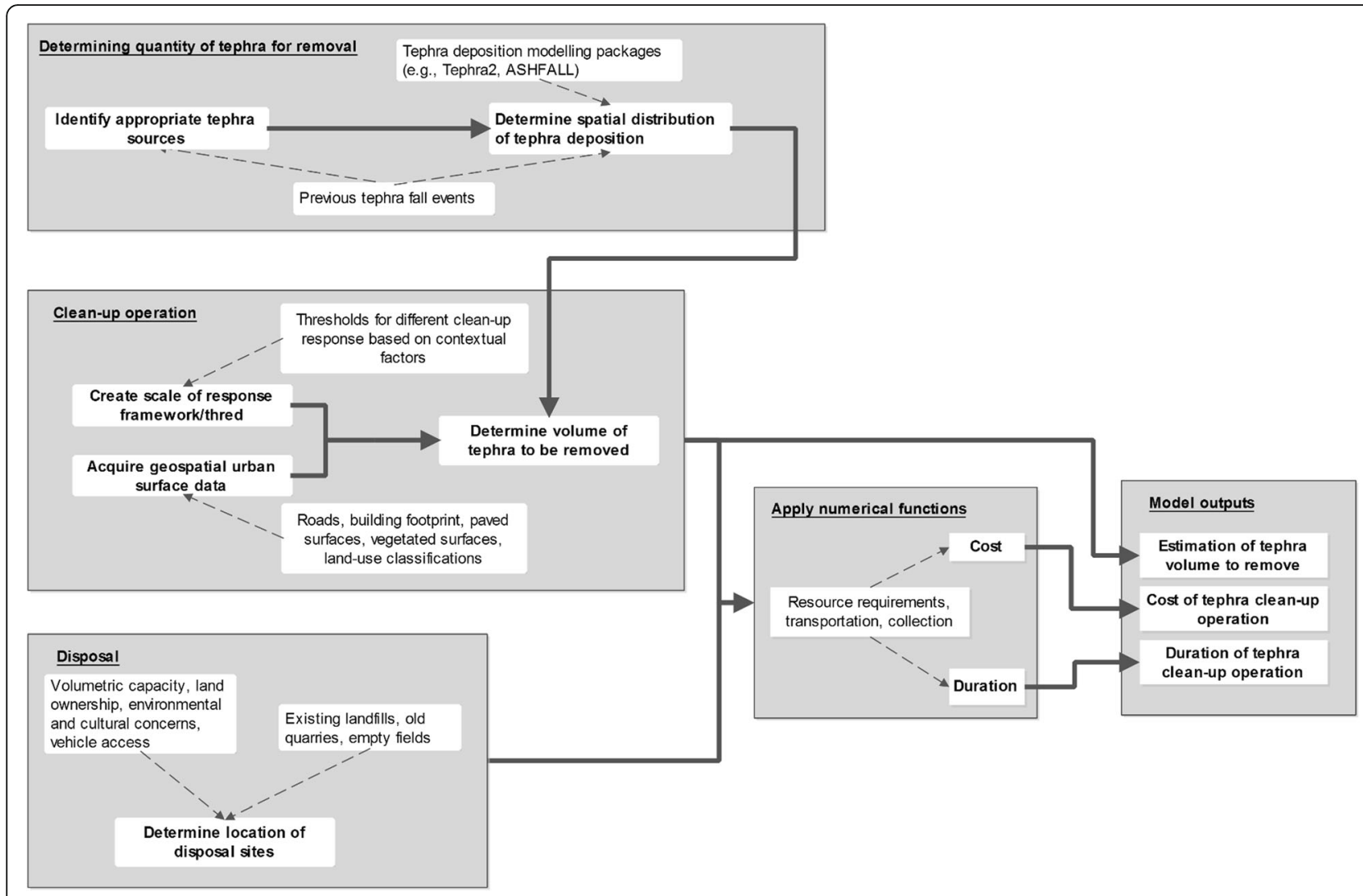

Fig. 3 Framework of tephra clean-up model. See text for explanations. Dotted lines indicate suggested options

Table 1 Generic and Auckland specific clean-up response thresholds for tephra clean-up operations (adapted from Hayes et al. 2015). See text for details on Auckland thresholds

\begin{tabular}{|c|c|c|c|}
\hline Tephra thickness & Generic clean-up response (Hayes et al. 2015) & $\begin{array}{l}\text { Tephra thickness } \\
\text { used in model }\end{array}$ & Auckland clean-up response \\
\hline$<0.5 \mathrm{~mm}$ & $\begin{array}{l}\text { Minor clean-up operations on roads using street } \\
\text { sweepers. Clean-up of airports. Property owners } \\
\text { self-manage clean-up. }\end{array}$ & $<1 \mathrm{~mm}$ & No coordinated clean-up \\
\hline $0.5-10 \mathrm{~mm}$ & $\begin{array}{l}\text { Coordinated clean-up of roads and airports using } \\
\text { street sweepers. Property owners self-managed } \\
\text { clean-up. }\end{array}$ & $1-10 \mathrm{~mm}$ & $\begin{array}{l}\text { Coordinated clean-up of roads and airport using } \\
\text { street sweepers. Property owners self-manage } \\
\text { clean-up (0.75-7.5 } \mathrm{m}^{3} \text { per property) }\end{array}$ \\
\hline $10-50 \mathrm{~mm}$ & $\begin{array}{l}\text { Coordinated clean-up of all roads and properties. } \\
\text { Heavy machinery such as diggers and loaders will } \\
\text { be required. Volunteer workforces may need to be } \\
\text { managed. Further clean-up of roads using street } \\
\text { sweepers may be required after the bulk of the } \\
\text { material is removed. }\end{array}$ & $>10-50 \mathrm{~mm}$ & $\begin{array}{l}\text { Coordinated clean-up of all roads, airports, and private } \\
\text { properties using labour, heavy machinery, and dump } \\
\text { trucks. Property owners dump tephra on roadside } \\
\left(7.5-40 \mathrm{~m}^{3} \text { per property) }\right.\end{array}$ \\
\hline \multirow[t]{2}{*}{$>50 \mathrm{~mm}$} & \multirow[t]{2}{*}{$\begin{array}{l}\text { Coordinated clean-up of all impervious surfaces } \\
\text { and recreational areas such as parks using heavy } \\
\text { machinery. High demand for heavy machinery. }\end{array}$} & $>50 \mathrm{~mm}-200 \mathrm{~mm}$ & $\begin{array}{l}\text { Coordinated clean-up of all areas using labour, heavy } \\
\text { machinery, and dump trucks. Property owners dump } \\
\text { tephra at roadside ( }>38 \mathrm{~m}^{3} \text { per property) }\end{array}$ \\
\hline & & $>200 \mathrm{~mm}$ & $\begin{array}{l}\text { Coordinated clean-up of all areas using labour, heavy } \\
\text { machinery, and dump trucks. Likelihood of considerable } \\
\text { building damaged requires a carefully managed clean-up } \\
\text { operation for health and safety }\end{array}$ \\
\hline
\end{tabular}


Community tolerance to ashy conditions will vary depending on local contextual factors such as the recurrence of tephra fall, environmental conditions (e.g., dry and windy conditions that exacerbate tephra remobilisation; Wilson et al. 2011; Reckziegel et al. 2016), socio-economic factors (e.g., reliance on tourism trade), environmental and public health standards, impacts to critical services, and the ability of property owners to self-manage clean-up (Hayes et al. 2015). Response thresholds are best developed in collaboration with the community, with an understanding of the available balance of official and community resources (Hayes et al. 2015).

\section{Considerations for cost and duration of clean-up operations}

Hayes et al. (2015) found that there is considerable variability in the duration and cost of tephra clean-up operations between different communities that have conducted cleanup operations. Thus, it is not possible to use hazardintensity metrics (e.g., volume or thickness) alone to estimate cost and duration. Therefore, we outline key phases of work that must be conducted as part of best-practice tephra clean-up operations; we do this here to estimate clean-up operation duration and cost (detailed in the following subsections). The following information is required to determine the cost and duration for clean-up operations:

- quantity of tephra to be collected and transported to disposal sites;

- methods of clean-up (e.g., sweeper truck or dump truck);

- the locations of where tephra is loaded onto trucks;

- locations of disposal sites;

- transport routes from and to disposal site; and

- collection (including manual labour), loading and transportation resources (e.g., trucks, street sweepers, paid and volunteer labour).

The methods of clean-up should be considered as part of assessing duration and cost because the most efficient method of clean-up will vary with tephra thickness. For example, global experience suggests that for urban areas with tephra deposition of $1-10 \mathrm{~mm}$ the use of street sweeper trucks is most likely to be utilised (Hayes et al. 2015). With greater thicknesses $(>10 \mathrm{~mm})$ some combination of manual labour, heavy machinery, and dump trucks is more efficient to remove the bulk of the material, with a potential final street sweeping operation to remove the fine residue, if necessary (Hayes et al. 2015).

For efficient organisation of clean-up operations, urban areas are often partitioned into smaller zones where clean-up activities are conducted simultaneously by crews assigned to that sector (Labelle et al. 2002; Hayes et al. 2015). For example, partitioning of urban areas is commonly used to model snow removal operations where specific disposal sites are assigned to a sector (Cook and Alprin 1976; Campbell and Langevin 1995; Labelle et al. 2002; Perrier et al. 2006a; b). Although tephra differs from snow in that it will not melt away, this approach to clean-up operations suits modelling of tephra clean-up.

Disposal sites are an integral aspect of tephra clean-up operations as they provide a permanent site for containment of tephra deposits (Hayes et al. 2015). Hence, potential tephra disposal sites will also need to be identified. Ideally, these sites will have adequate capacity for the tephra volume requiring disposal, access for large trucks and machinery, and be as close as reasonably possible to clean-up areas. Provisions should also be made to ensure the disposal site has low susceptibility to erosion and leaching into groundwater (Dolan et al. 2003). Typical locations used for tephra disposal include existing waste landfills, old quarries, and empty fields (Hayes et al. 2015). If more than one disposal site is to be utilised it will be necessary to assign optimal disposal sites to sectors (e.g., neighbourhoods) to manage volumes and traffic congestion.

\section{Modelling duration of clean-up using dump trucks}

Here we present a series of equations for clean-up duration where dump trucks are used to transport bulk quantities of tephra to disposal sites, adapted from work by Peurifoy and Schexnayder (2002) based on civil works projects. Variables are listed and defined in Table 2.

Clean-up generally requires the following phases of work to occur (Hayes et al. 2015):

1. Tephra removed from property and placed at roadside

2. Tephra piled at a pickup point by heavy machinery

3. Trucks loaded with tephra at pickup point

4. Truck travels to disposal site and unloads tephra

5. Truck returns to a pickup point to reload.

Practically, phases 1-2 can occur constantly throughout the process. Therefore, with respect to duration, our model only considers phases 3-5 under the assumption that pickup points will be replenished while trucks are travelling to and from disposal sites.

The time it takes to complete clean-up operations depends on the number of trips to move material to disposal sites and how long each trip takes to complete, following an initial delay while material is moved from clean-up site to pick-up sites. The number of truck trips will depend on the volume capacity of the trucks within the fleet. The duration of each truck trip depends on the time to load trucks, haul tephra from pickup points to disposal sites, unload tephra at disposal sites, and then return to a pickup point to be reloaded. 
Table 2 Model parameters and definitions

\begin{tabular}{|c|c|}
\hline Variable & Definition \\
\hline $\mathrm{B}_{\mathrm{s}}$ & Bucket swings \\
\hline$T_{v}$ & Truck volume $\left(\mathrm{m}^{3}\right)$ \\
\hline$B_{v}$ & Bucket volume $\left(\mathrm{m}^{3}\right)$. \\
\hline$L_{t}$ & Loading time \\
\hline $\mathrm{B}_{\mathrm{c}}$ & Bucket cycle time \\
\hline$T_{c}$ & Truck cycle time \\
\hline $\mathrm{H}_{\mathrm{t}}$ & Hauling time \\
\hline$Q_{t}$ & Queuing time \\
\hline$U_{t}$ & Unloading time \\
\hline $\mathrm{F}_{\mathrm{t}}$ & Fleet hauling time \\
\hline$P_{t}$ & Time from a pickup point to a disposal site \\
\hline $\mathrm{H}_{\mathrm{d}}$ & Hours per day clean-up works occurs \\
\hline $\mathrm{T}$ & Duration of clean-up (days) \\
\hline$F_{c}$ & Fleet cycles (Fleet hauling capacity/Nolume to transport) \\
\hline $\mathrm{N}_{\mathrm{t}}$ & Number of dump trucks available for clean-up \\
\hline $\mathrm{N}_{s}$ & Number of sweepers available for clean-up \\
\hline$D_{\mathrm{km}}$ & Distance of road required to be cleaned \\
\hline$D_{d}$ & Distance of road cleaned per day \\
\hline$L_{r}$ & $\begin{array}{l}\text { Length of road that one sweeper truck can clean } \\
\text { per day ( } \mathrm{km} / \text { day) }\end{array}$ \\
\hline$S_{v}$ & Speed of sweeper truck (km/h) \\
\hline $\mathrm{H}_{\mathrm{f}}$ & $\begin{array}{l}\text { Fraction of each hour spent travelling to and from } \\
\text { disposal sites }\end{array}$ \\
\hline E & $\begin{array}{l}\text { Efficiency factor (how many times a sweeper needs to } \\
\text { pass over a surface to remove } 100 \% \text { of tephra) }\end{array}$ \\
\hline V & Volume of tephra $\left(\mathrm{m}^{3}\right)$ \\
\hline $\mathrm{D}$ & Kilometres to a disposal site \\
\hline
\end{tabular}

In Eqs. 1 to 3 we conceptually outline the process of how to assess clean-up duration based on a single dump truck. Then in Eqs. 4 and 5 we demonstrate how to apply this conceptual process to a fleet of trucks. Truck loading time depends on the required number of bucket swings $\left(B_{s}\right)$ from a loader to fill a truck (Fig. 4), which depends on the capacity of the bucket on the loader and capacity of the truck being loaded:

$$
B_{s}=T_{v} / B_{v}
$$

where $B_{s}=$ Bucket swings, $T_{v}=$ Truck volume $\left(\mathrm{m}^{3}\right)$, and $\mathrm{B}_{\mathrm{v}}=$ Bucket volume $\left(\mathrm{m}^{3}\right)$.

In practice, it is inefficient to underload a bucket (scoop up less than a full bucket) to match the exact volumetric capacity of a truck (Peurifoy and Schexnayder 2002). This means that $B_{s}$ is an integer, which can either be rounded down (fewer bucket loads and less tephra per truck) or rounded up (excess spills off the truck). Here, $B_{s}$ is rounded up to ensure full trucks are used. Peurifoy and Schexnayder (2002) suggest loading time can then be determined as per Eq. 2:

$$
L_{t}=B_{s} x B_{c}
$$

where $\mathrm{L}_{\mathrm{t}}=$ loading time, $\mathrm{B}_{\mathrm{s}}=$ Bucket swings, and $\mathrm{B}_{\mathrm{c}}=$ Bucket cycle time (time to collect a load and dump it in a truck).

Truck cycle time $\left(\mathrm{T}_{\mathrm{c}}\right)$ is the time it takes for a truck to complete a clean-up cycle: (1) load, (2) travel to disposal, (3) queuing at the disposal site, (4) unload, and (5) return to the pick-up point for the next cycle. Truck cycle time can be estimated based on Eq. 3 (adapted from Peurifoy and Schexnayder 2002). Queuing times are dependent on operational capacity of disposal sites (number of trucks a disposal site can accept per hour or day):

$$
T_{c}=L_{t}+\left(H_{t} x 2\right)+Q_{t}+U_{t}
$$

where $\mathrm{T}_{\mathrm{c}}=$ Truck cycle time, $\mathrm{L}_{\mathrm{t}}=$ Loading time, $\mathrm{H}=$ Hauling time, $\mathrm{Q}_{\mathrm{t}}=$ queuing time, and $\mathrm{U}_{\mathrm{t}}=$ Unloading time. We apply a doubling factor to $H_{t}$ to consider the return journey.

Equation 3 applies to the duration for a single truck to complete a clean-up cycle. However, in reality, clean-up operations utilise fleets of trucks of varying types and sizes. Thus, we now adapt this conceptual equation of a single truck to consider characteristics of the entire truck fleet. One of these characteristics is the fleet hauling capacity, which is the volume of material the entire fleet could carry in a single clean-up cycle (i.e., summed volumetric capacity of every truck in the fleet). The other important characteristic is the fleet hauling time. This is the hauling time it would take the fleet to travel from every pick-up point to the designated disposal site. In this model, we assume all truck types travel at the same speed (depending on road speed restrictions). Therefore, fleet hauling time is calculated using Eq. 4:

$$
\mathrm{F}_{\mathrm{t}}=\left(\sum \mathrm{P}_{\mathrm{t}}\right) / \mathrm{N}_{\mathrm{t}}
$$

where $F_{t}=$ fleet hauling time, $P_{t}=$ time from a pickup point to a disposal site, and $\mathrm{N}_{\mathrm{t}}=$ number of trucks within the fleet. Clean-up operation duration can then be estimated by accounting for the hours per day that transportation of material would be done:

$$
\mathrm{T}=\left(\left(\mathrm{F}_{\mathrm{t}} \mathrm{x} 2\right)+\mathrm{F}_{\mathrm{c}} \mathrm{x}\left(\mathrm{L}_{\mathrm{t}}+\mathrm{U}_{\mathrm{t}}\right)\right) / \mathrm{H}_{\mathrm{d}}
$$

where $\mathrm{T}=$ Clean-up duration (days), Fc $=$ Fleet cycles (Fleet hauling capacity/volume to transport), and $\mathrm{h}_{\mathrm{d}}=$ Hours per day transportation works occurs.

\section{Street sweepers}

Similar to dump trucks, street sweepers have a maximum volumetric capacity with which they can collect 

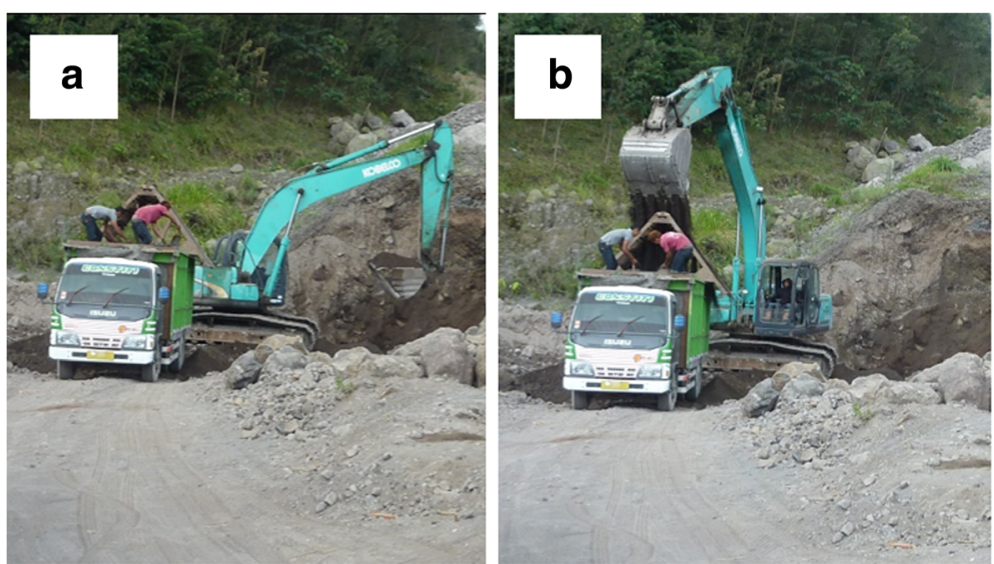

Fig. 4 a Start of bucket cycle, b end of bucket cycle (Photo: Josh Hayes)

material. However, they collect material by sweeping across a surface and not from specific pick-up points. Therefore, the duration for clean-up using street sweepers requires an adjusted equation to account for this (Eq. 6).

$$
\mathrm{T}=\mathrm{D}_{\mathrm{km}} / \mathrm{D}_{\mathrm{d}}
$$

where $D_{k m}=$ distance of road lanes required to be cleaned, and $D_{d}=$ distance of road lanes a sweeping fleet can clean per day. To solve this equation, the following are required: (1) total length of road requiring cleaning, (2) number of sweeper trucks, (3) speed of sweeping, and (4) efficiency of sweeping.

The total volume of road requiring cleaning is determined by exposure analysis of road length within the $<10 \mathrm{~mm}$ tephra zone. We assume that a sweeper is able to clean the width of a single lane of road. To determine the cumulative distance of road cleaned per hour, the length of road lanes a single sweeper truck can clean per hour is multiplied by the number of sweeper trucks available for clean-up operations:

$$
\mathrm{D}_{\mathrm{d}}=\mathrm{L}_{\mathrm{r}} \mathrm{x} \mathrm{n}_{\mathrm{s}}
$$

where $L_{r}=$ Length of road that one sweeper truck can clean per hour $(\mathrm{km} / \mathrm{h})$, and $\mathrm{n}_{\mathrm{s}}=$ number of sweepers available for clean-up activity.

To determine $L_{r}$, the truck speed while sweeping is required. It is also important to consider time spent travelling to and from disposal sites as this will influence the total time a sweeper truck spends sweeping per day. Additionally, experiences of street sweeping operations to remove tephra from roads suggest roads will need multiple cleanings due to the inefficiencies of sweeper trucks in removing fine-grained tephra, and potential remobilisation of tephra (Blong 1984; Hayes et al. 2015).
This inefficiency will need to be factored into the length of road that is cleaned per day. Therefore:

$$
\mathrm{L}_{\mathrm{r}}=\mathrm{H}_{\mathrm{d}} \mathrm{x}\left(\left(\mathrm{S}_{\mathrm{V}} \mathrm{x}\left(1-\mathrm{H}_{\mathrm{f}}\right)\right) / \mathrm{E}\right)
$$

where $S_{v}=$ speed of a sweeper truck $(\mathrm{km} / \mathrm{h}), \mathrm{H}_{\mathrm{f}}=$ fraction of each hour spent travelling to and from disposal sites, and $E=$ Efficiency factor (how many times a sweeper would need to pass over a surface to remove all tephra).

\section{Clean-up operation cost}

Hayes et al. (2015) found that there is a poor correlation between clean-up operation cost and tephra accumulation, and therefore cost relationships as a function of discrete tephra fall are not appropriate for use in this analysis. To illustrate how to incorporate costs into the model we use tephra clean-up costs specifically estimated for Auckland by Johnston et al. (2001) and adjusted for inflation to 2015 New Zealand dollars (Reserve Bank of New Zealand 2016a). This equates to approximately 45 cents per $\mathrm{m}^{3}$ per $\mathrm{km}$ to disposal sites for transportation. The cost of disposal is estimated at $\$ 4$ per $\mathrm{m}^{3}$. We use these values as a proxy for total clean-up cost to municipal authorities and discuss the uncertainties associated with these values in more detail in the section entitled: "Uncertainties relating to clean-up costs". We use both of Johnston et al. (2001)'s rates to consider clean-up costs (Eq. 9):

$$
\text { Clean-up cost }=(0.45 \times \mathrm{V} \times \mathrm{D})+4 \times \mathrm{V}
$$

where $\mathrm{V}=$ Volume of tephra removed in cubic metres, and $\mathrm{D}=$ Kilometres to a disposal site. 


\section{Application of the model to Auckland, New Zealand}

In the following sections we describe the application of this conceptual model and the development of equations for scenarios specific to Auckland, New Zealand.

\section{Auckland tephra hazard}

We use deterministic distal (vent $>100 \mathrm{~km}$ from Auckland) and local eruption scenarios to represent two main sources of tephra impacting the Auckland metropolitan area and to demonstrate the utility of our clean-up model.

\section{Distal eruption clean-up scenarios}

We present two distal scenarios for clean-up modelling purposes: (1) thin distal tephra fall $(1 \mathrm{~mm})$, and (2) thick distal tephra fall $(10 \mathrm{~mm})$ across the urban Auckland region. These two scenarios were selected to test the model under different clean-up methods: 1) street sweeping operation for thin tephra deposition, and 2) heavy machinery and dump truck operation for thick tephra deposition. We adopt a uniform distribution of tephra for simplicity, acknowledging in reality there would be variability in deposit thickness as a result of attenuation from the source and localised thickening due to topographic effects.

\section{Local eruption clean-up scenario}

Eruptions within the AVF can occur anywhere within metropolitan and offshore areas, and water availability influences eruption type (wet explosive or dry magmatic) (Kereszturi et al. 2014). Among AVF eruptions there is considerable variation in erupted volumes of material (Kereszturi et al. 2013). Our scenarios represent the dominant eruption sequence within the AVF, which begins with wet explosive behaviour that transitions into dry effusive activity (Kereszturi et al. 2014). A largevolume pyroclastic deposition, inspired by the prehistoric Three Kings eruption ( $28.5 \mathrm{ka})$, is used to explore a potential upper bound clean-up operation, referred to here as 'Local One' (L1) eruption scenario (Fig. 5a). Our 'Local Two' (L2) eruption scenario assumes a more modest deposition of pyroclastic material, and has previously been used to assess volcanic hazard impacts to critical infrastructure within Auckland (Deligne et al. 2015) (Fig. 5b). Both local scenarios are explosive, but it should be noted that some previous eruptions of the AVF have been predominantly effusive.

Currently, there is no published information on tephra distribution for the Three Kings eruption. For this reason, to develop the L1 eruption scenario, we examined unpublished mapped tuff thickness data (S. Cronin pers comm 2016) and assigned crude elliptical isopach approximations for deposit thickness from the estimated vent out to $1 \mathrm{~m}$ thickness. Then for relatively distal tephra thicknesses
$(<1 \mathrm{~m})$ we drew on the deposit thickness of Three Kings tephra identified in lake cores (Hopkins et al. 2015). As further work is required to define a more robust extent of the Three Kings tephra distribution, we use the resultant L1 eruption scenario only for the purposes of depicting a plausible high pyroclastic volume eruption across central Auckland.

The L2 eruption scenario is a more typical pyroclastic volume for wet explosive eruptions within the AVF when comparing to volume estimates presented in Kereszturi et al. (2013). This scenario differs from the L1 eruption scenario in that estimating the distribution of tephra has considered multiple eruptive phases that result in a less elliptical tephra deposition. This hypothetical eruption begins with a phreatic eruption with a pyroclastic surge extending $6 \mathrm{~km}$ from the vent location. This is followed by phreatomagmatic eruptions, which first produce tephra deposition to the west and a second surge deposit, followed by tephra deposition to the north-west and then minor deposition to the south-east. Here, we assume both surge and fallout deposits will be cleaned up. For a full description of the scenario we refer the reader to Fitzgerald et al. (2016) and Deligne et al. (2015).

\section{Tephra clean-up response thresholds for Auckland}

We present the Auckland-specific clean-up response thresholds in Table 1 and use these thresholds to create four zones of clean-up in Auckland. To determine thresholds, we considered thickness for initiating: (1) coordinated clean-up operations of roads, (2) coordinated clean-up of private properties, (3) clean-up of vegetated areas, and (4) areas where considerable building damage is possible.

To determine the capability of private property owners to self-manage clean-up we use public policy and past clean-up operations. In New Zealand, it is the responsibility of the property owner to organise clean-up of their properties (both residential and commercial) (Earthquake Commission 2015); thus where possible we assume that property owners will generally self-manage this. An example of this approach being taken was after the Mt. Ruapehu eruptions of 1995-96 in Rotorua, New Zealand ( $\sim 1 \mathrm{~mm}$ thickness) where only roads and the Rotorua Central Business District were cleaned as part of a coordinated clean-up response, with residents self-managing clean-up (Johnston et al. 2000). Clean-up of liquefaction ejecta (silt and fine sand) in Christchurch, New Zealand after the 2010-2011 earthquakes also demonstrated that volunteer groups will often assist with clean-up activities (Villemure et al. 2012); this greatly assists those such as the elderly and infirm who have difficulty with the physical labour involved with clean-up. Use of volunteers has also been noted in various tephra fall clean-up operations globally (Hayes et al. 2015). The land area for the median residential property in Auckland is around $750 \mathrm{~m}^{2}$, around 


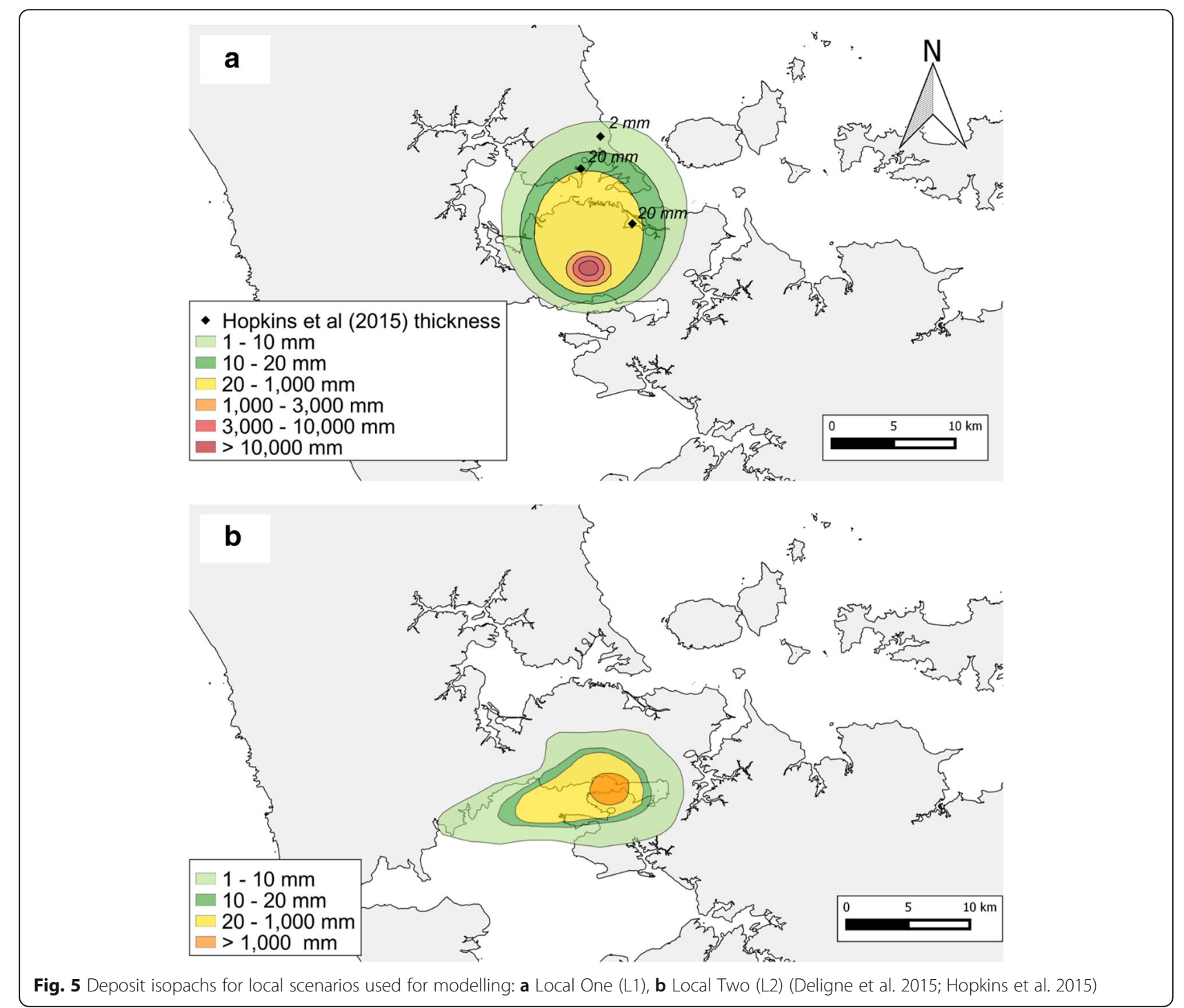

$30 \%$ of which is made up of gardens and lawns. Tephra thickness up to $10 \mathrm{~mm}$ would result in up to $7.5 \mathrm{~m}^{3}$ of tephra deposited for the median residential property. If the tephra that is deposited on roofs, driveways, and other impervious surfaces of residential properties were added to the vegetated areas it would correspond to a thickness of around $30 \mathrm{~mm}$ on these surfaces. Thus, only some of the tephra that is deposited on residential properties at less than $10 \mathrm{~mm}$ would need to be disposed of off-site. We assume that individual property owners will be able to cope with such volumes of tephra, and that coordinated municipal clean-up operations would occur only for roads. However, this is still a considerable volume of material to clean-up, even if it is not disposed of off-site. It is also conceivable that some tephra from residential properties below this threshold could be added to municipal cleanup operations depending on factors such as the severity of impacts occurring due to tephra deposition, level of remobilisation occurring, and residents dumping tephra from their properties on the roads or other public areas. Thus our threshold is an approximation only and should not be considered as hard rule.

For tephra thicknesses of $>10-50 \mathrm{~mm}$, the total volume deposited in a median residential property increases to $\sim 40 \mathrm{~m}^{3}$, which is likely to be too much to be added to gardens and lawns. This means that for tephra thickness of > 10-50 mm, tephra will require off-site disposal. We suggest it will be more efficient for this tephra to be included within the coordinated clean-up operations and collected and removed when roads are cleaned (Hayes et al. 2015). Therefore, we have chosen a threshold of $10 \mathrm{~mm}$ to initiate the inclusion of private residential and commercial properties within coordinated clean-up operations.

At thicknesses $>10 \mathrm{~mm}$ bulk tephra will be collected using manual labour and heavy machinery because street sweepers are not very efficient at picking up tephra of 
this thickness. The local eruption scenarios have highly variable deposit thicknesses, ranging from $1 \mathrm{~mm}$ to $>10 \mathrm{~m}$. Thus, for local eruption scenarios, there is a combination of different clean-up methods which utilise both street sweeping and heavy machinery. For this reason, we assign four different clean-up zones for local scenarios, using the thresholds from Table 1.

Finally, we assume no clean-up occurs within a $500 \mathrm{~m}$ radius of the vent due to complete destruction from initiating eruptive activity (e.g., edifice formation and explosion craters).

\section{Disposal site identification}

Dolan et al. (2003) identified 16 potential sites for tephra disposal within Auckland metropolitan area, which have since been adopted into the Auckland Volcanic Field Contingency Plan (ACDEM 2015). We use these disposal sites within the tephra clean-up model (see Fig. 2). The Auckland Volcanic Contingency Plan states that in the event of a local eruption a $5 \mathrm{~km}$ evacuation and exclusion zone will be put in place (ACDEM 2015). Disposal sites within evacuation zones (assumed as a $5 \mathrm{~km}$ buffer around the vent location) are excluded from this analysis as it is unlikely they will be functional for an immediate clean-up response although they may become viable once the evacuation zone is lifted or reduced.

\section{Determining duration and cost of clean-up operations in Auckland \\ Determining optimal disposal sites}

We conducted geospatial road network modelling ${ }^{1}$ to determine the optimal disposal sites. This was conducted by calculating the cost (based on time or distance) from a point of origin to a destination point. In the context of our clean-up model, an origin is the point tephra is loaded onto a truck and a destination is a disposal site.

To assign origin points, we partitioned Auckland into smaller geographical areas. In Auckland it is likely that clean-up will be organised at the spatial scale of suburban blocks encompassing several streets; a similar approach was taken with clean-up of earthquake-induced liquefaction ejecta in Christchurch, New Zealand (Villemure et al. 2012). To model clean-up operations we used current Auckland metropolitan area meshblocks; these are the smallest spatial unit used for the New Zealand Census, and thereby provide the finest spatial resolution for describing population characteristics. The median area of the meshblocks in the dataset is $\sim 40,000 \mathrm{~m}^{2}$. For each meshblock the total volume of tephra requiring removal was determined based on our thickness thresholds, and by calculating the volume of tephra on different surfaces using the surface area of roads, building footprint (as a proxy for roof area) and other impervious surfaces (e.g., car parks, driveways) (Fig. 6). For context, we present median percentages of meshblock area occupied by different surfaces (Table 3 ).

Within each meshblock adjacent to a road we randomly assigned one point as a pick-up point (origin) for trucks to transport material to disposal sites (destinations) (Fig. 7). Speed limits for each road section were used to determine travel time between pick-up points and disposal points; for simplicity, we did not use traffic modelling software as the post-disaster traffic environment is difficult to predict. We selected disposal sites for each meshblock based on the fastest travel time from a pick-up point to a disposal site; this permitted estimation of minimum clean-up duration. In most cases, the same disposal site was the closest both by distance and travel time.

Because site-specific designs are unavailable for the identified disposal sites, the model assumes that identified disposal sites have the volumetric capacity for any volume of material required (i.e., potentially infinite capacity). However, with more site-specific information for disposal sites, constraints on volumetric capacity could be added to the model to close a site when capacity is reached.

\section{Model inputs and Monte Carlo modelling}

Due to uncertainties associated with some model inputs for the equations presented earlier, we used Monte Carlo sampling and ran 10,000 iterations of the cost and duration models using the input parameters in Table 4.

The distance a street sweeper can travel before reaching capacity will depend on sweeper ability to pick up material (efficiency) as well as the volume of material on a section of road. The efficiency of street sweepers to remove fine-grained material varies depending on sweeper type and grain size of the material being removed (Dupree 2011). Removal efficiencies (proportion of material removed from the road) in real-world conditions have been measured as being as low as 10\% (Selbig and Bannerman 2007). In Portland, U.S.A., following the 1980 Mt. St. Helens eruption, sweepers were reported to be removing $\sim 50 \%$ of fine-grained (median grain size $\sim 31$ microns; Shulters and Clifton 1981) tephra from roads. As there is no definitive information on the efficiency of street sweepers to removing tephra, we assume that sweeper efficiency factors (defined in Table 2) are between 1 and 10 passes with 2 passes being most likely based on experiences in Portland, U.S.A. (Table 4). Cost of roadside maintenance sweeping was not available, so we have adopted costs for maintenance sweeping from Schilling (2005). These costs were converted from US dollars to 2015 New Zealand dollars ${ }^{2}$, which yielded rates of NZ\$45-90 per curb-kilometre depending on the type of sweeper (Schilling 2005). The street sweeper resources (make/model and quantity available) in 


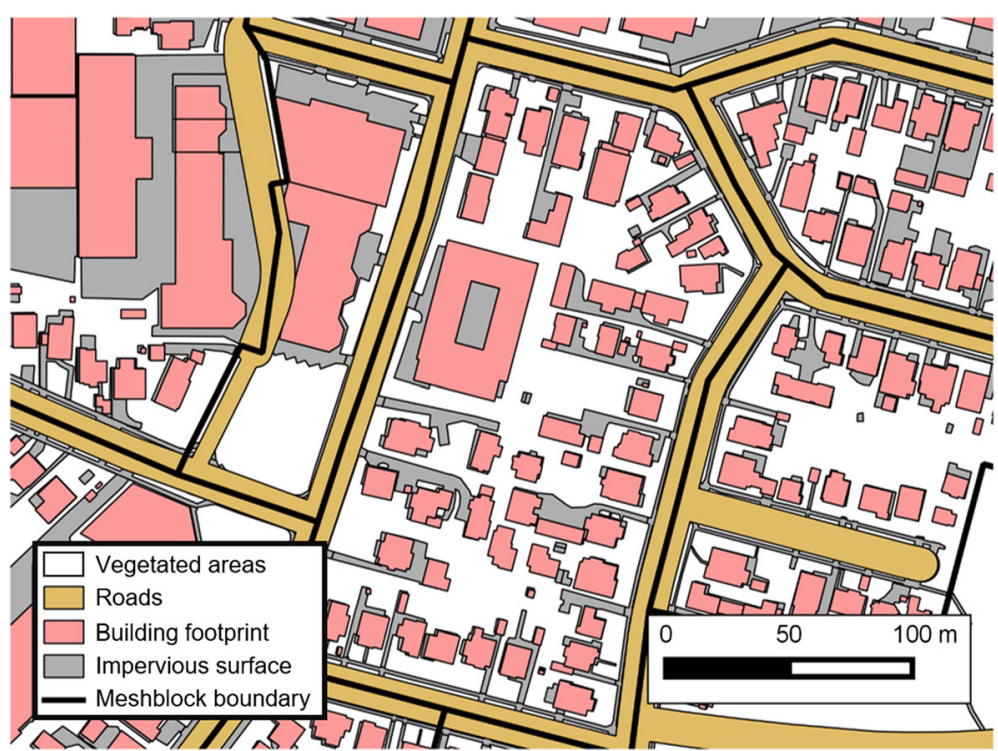

Fig. 6 Example of surface classification used for calculating the volume of tephra to be removed from different surfaces

Auckland were not available for this study, so we made assumptions regarding volume capacities of sweeper trucks, the number of sweeper trucks, and speed of street sweeping (Table 4). The speed of sweeping was based on sweeping best practice guidelines suggesting speeds of between 5 and $7 \mathrm{~km} / \mathrm{h}$ (Sutherland and Kidwell-Ross 2010). Typical street sweeper volume capacities are between 5 and $7 \mathrm{~m}^{3}$ (Schilling 2005). This means that when cleaning roads with $1 \mathrm{~mm}$ of tephra each sweeper at $100 \%$ efficiency would be able to clean $1.7-2.3 \mathrm{~km}$ of road lanes before needing to unload (about 20 min of cleaning). The time it takes to travel to a disposal site and unload is a challenging component to consider because: sweepers will be dynamically moving through a road network; we do not have route plans sweepers will take (indeed we argue these would likely be formed on a daily basis during a real clean up event); and there is high uncertainty associated with the efficiency of street sweepers. It is therefore difficult to determine the point along a road network at which a sweeper will need to travel to a disposal site to unload. We estimate the proportion of each hour a sweeper would spend not actually cleaning (e.g., travelling to and from disposal sites) as being between 0.17 and 0.5 based on the assumption that sweepers would use disposal sites that have been identified within the Auckland Volcanic Contingency Plan, which are widely distributed throughout the Auckland Metropolitan area (ACDEM 2015). We assumed there would be $10-40$ street sweepers, with 20 being the most likely number. This is possibly a conservative estimate, as in an emergency extra sweeper trucks could be sourced from outside the region, but sweepers could be limited if other regions are also affected by tephra fall.

Dump truck types and body volumes are based on truck types used for liquefaction ejecta clean-up in Christchurch that were described after interviews with contractors managing the clean-up operation (Villemure M: Fine grained sediment clean-up in a modern urban environment. Unpublished). We engaged with Auckland Council Solid Waste department to guide our estimation of trucks and the types used. This was an area of great uncertainty for them, and they indicated they would likely pull extra resources in from the private market (Auckland Solid Waste, pers comm 2014). For this

Table 3 Characteristics of selected land use types for our Auckland meshblock exposure inventory

\begin{tabular}{|c|c|c|c|c|c|c|}
\hline \multirow[t]{2}{*}{ Land-use zone } & \multirow{2}{*}{$\begin{array}{l}\text { Auckland Unitary Plan zones (Auckland } \\
\text { Council, 2016) }\end{array}$} & \multicolumn{4}{|c|}{ Median percentage of meshblock area } & \multirow{2}{*}{$\begin{array}{l}\text { Median area of } \\
\text { meshblock }\left(\mathrm{m}^{2}\right)\end{array}$} \\
\hline & & Roofs & Impervious surfaces & Road & Vegetation & \\
\hline City Centre & City Centre & 24 & 12 & 14 & 51 & 12,000 \\
\hline Residential & $\begin{array}{l}\text { Mixed Housing, Single House, Terrace Housing } \\
\text { and Apartment Building }\end{array}$ & 19 & 17 & 7 & 58 & 35,000 \\
\hline Public open space & $\begin{array}{l}\text { Conservation, Informal Recreation, Sport and } \\
\text { Active Recreation }\end{array}$ & 4 & 7 & 3 & 86 & 125,000 \\
\hline Public and private Industry & Light Industry, Heavy Industry & 24 & 31 & 5 & 40 & 124,000 \\
\hline
\end{tabular}




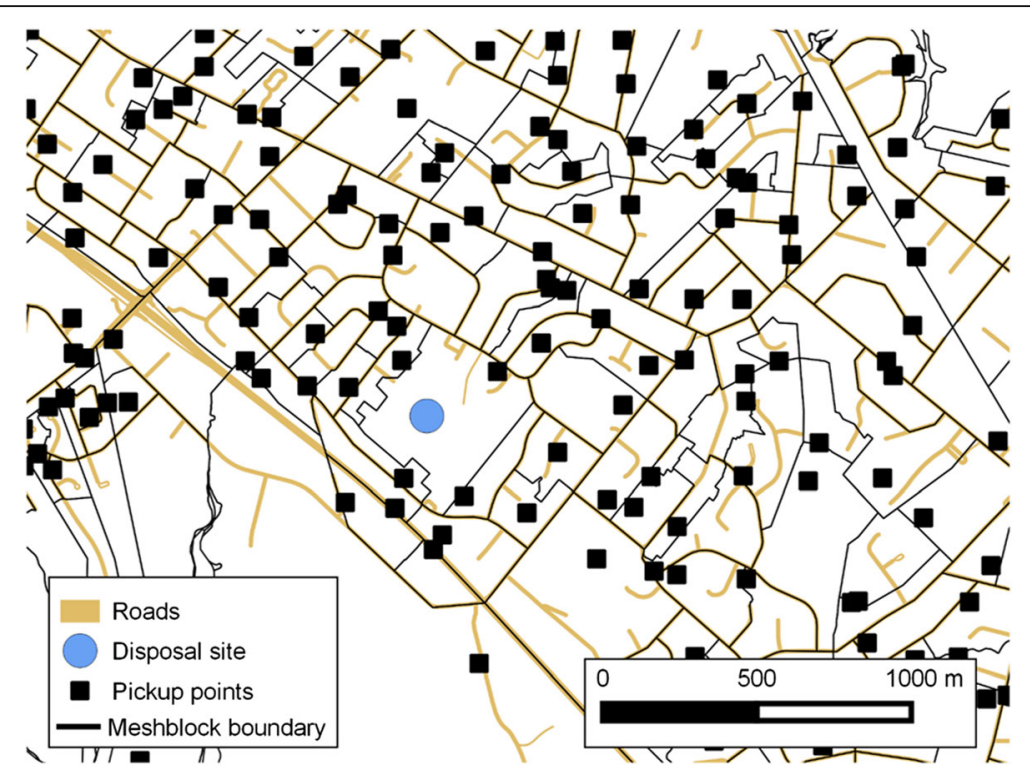

Fig. 7 Example of pick-up and destination points within meshblocks for one disposal site. Area of icon for disposal site is not to scale, and meshblock boundaries follow roads

reason, the number of trucks available is currently unknown. Here we assume that at least one of each truck type is available and that a maximum of 100 of each is possible, with 50 of each truck type the most likely. Auckland Council officials considered this estimate reasonable (Auckland Solid Waste, pers comm 2014). Truck unloading times are likely to vary depending on the conditions at a disposal site (e.g., space to manoeuvre, potential bottlenecks). Peurifoy and Schexnayder (2002) suggest that unloading times are approximately $1.5 \mathrm{~min}$ for reardump trucks. However, it is important to consider that disposal sites identified within the Auckland Volcanic Field Contingency Plan (ACDEM 2015) are almost entirely recreational parks, and so are not designed for the movement of dump trucks and other heavy machinery. Hence, we made the assumption that dumping time will be at least $2 \mathrm{~min}$, with a maximum of $10 \mathrm{~min}$ and a mean time of 5 min (Table 4).

We assumed that transportation of tephra will occur from anywhere between 12 and $24 \mathrm{~h}$ per day. A higher weighting has been given to $12 \mathrm{~h}$ per day because disposal sites are located in residential areas, probably making a 24-h operation unacceptable to residents living near disposal sites or along transportation routes.

\section{Model outputs}

\section{Removal volumes}

The total volume of tephra removed for each scenario is presented in Table 5. Clean-up of the thin distal eruption scenario where only roads are cleaned requires disposal of $\sim 3.6 \times 10^{4} \mathrm{~m}^{3}$, or $2.5 \%$ of the average annual waste from all sources for Auckland $\left(1.5 \times 10^{6} \mathrm{~m}^{3}\right.$; Auckland
Council 2011). Conversely, clean-up of the thicker distal eruption produces $2.2 \times 10^{6} \mathrm{~m}^{3}$, or nearly 1.5 times the average annual waste disposal.

In the L1 eruption scenario, approximately $5.9 \times 10^{7} \mathrm{~m}^{3}$ of tephra, mostly from zone 4 , is estimated to require removal; this is the equivalent of $\sim 40$ years of waste for Auckland. The less voluminous L2 eruption scenario will require about $8 \times 10^{6} \mathrm{~m}^{3}$ of tephra to be removed, similar to L1, mostly from zone 4 . These estimates do not include the potentially substantial volume of construction and demolition waste likely to be generated by such an event due to heavy tephra fall, and associated building and infrastructure damage, and demolition.

\section{Clean-up cost}

Model outputs indicate that local eruption clean-up costs vary considerably between to two eruption scenarios (Table 6). Clean-up of the high-volume L1 eruption scenario could incur clean-up costs of NZ\$300-700 million ( US\$210-510 million, 10th-90th percentile), whilst clean-up costs of the low-volume L2 scenario will incur tephra clean-up costs between NZ\$50-100 million ( US\$35-70 million, 10th-90th percentile).

These values should be considered estimates as there are many factors that could influence clean-up costs that are not considered here, such as managing volunteer labour, equipment hire, and equipment maintenance (see section "Uncertainties relating to clean-up costs" for more detail). Thus, the costs of tephra clean-up activities require further investigation to obtain more robust overall cost estimates. 
Table 4 Monte Carlo model parameters

\begin{tabular}{|c|c|c|c|c|c|}
\hline \multicolumn{6}{|l|}{ Duration model } \\
\hline Category & Name & Distribution $^{a}$ & Minimum & Mean & Maximum \\
\hline \multirow[t]{5}{*}{ Street sweepers } & Operation hours & Discrete & $12 \mathrm{~h}$ & - & $24 \mathrm{~h}$ \\
\hline & Number available & Triangle & 10 & 20 & 40 \\
\hline & Sweeping speed & Triangle & $5 \mathrm{~km} / \mathrm{h}$ & $6 \mathrm{~km} / \mathrm{h}$ & $7 \mathrm{~km} / \mathrm{h}$ \\
\hline & Disposal time & Triangle & 0.17 & 0.25 & 0.5 \\
\hline & Efficiency factor & Triangle & 1 & 2 & 10 \\
\hline \multirow[t]{3}{*}{$4 \times 2$ trucks } & Volume capacity & Uniform & $7 \mathrm{~m}^{3}$ & $7.5 \mathrm{~m}^{3}$ & $8 \mathrm{~m}^{3}$ \\
\hline & Number available & Triangle & 1 & 50 & 100 \\
\hline & Unloading time & Triangle & 2 mins & 5 mins & 10 mins \\
\hline \multirow[t]{3}{*}{6 wheeler trucks } & Volume capacity & Uniform & $10 \mathrm{~m}^{3}$ & $15 \mathrm{~m}^{3}$ & $20 \mathrm{~m}^{3}$ \\
\hline & Number available & Triangle & 1 & 50 & 100 \\
\hline & Unloading time & Triangle & 2 mins & 5 mins & 10 mins \\
\hline \multirow[t]{3}{*}{8 wheeler trucks } & Volume capacity & Uniform & $19 \mathrm{~m}^{3}$ & $23 \mathrm{~m}^{3}$ & $27 \mathrm{~m}^{3}$ \\
\hline & Number available & Triangle & 1 & 50 & 100 \\
\hline & Unloading time & Triangle & 2 mins & 5 mins & 10 mins \\
\hline \multirow[t]{3}{*}{10 wheeler trucks } & Volume capacity & Uniform & $10 \mathrm{~m}^{3}$ & $37 \mathrm{~m}^{3}$ & $64 \mathrm{~m}^{3}$ \\
\hline & Number available & Triangle & 1 & 50 & 100 \\
\hline & Unloading time & Triangle & 2 mins & 5 mins & 10 mins \\
\hline Operation hrs & & Discrete & $12 \mathrm{~h}$ & - & $24 \mathrm{~h}$ \\
\hline \multirow[t]{9}{*}{ Bucket loader } & Scenario modelled & Uniform & 1 & - & 4 \\
\hline & 1 - Capacity & Triangle & 0.7 & 1.5 & 2.3 \\
\hline & 1 - Swing time & Triangle & 27 & 28 & 30 \\
\hline & 2 - Capacity & Triangle & 3 & 3.5 & 4 \\
\hline & 2 - Swing time & Triangle & 30 & 31.5 & 33 \\
\hline & 3 - Capacity & Triangle & 4.5 & 5 & 5.5 \\
\hline & 3 - Swing time & Triangle & 33 & 34.5 & 36 \\
\hline & 4 - Capacity & Triangle & 10 & 14 & 18 \\
\hline & 4 - Swing time & Triangle & 36 & 39 & 42 \\
\hline \multicolumn{6}{|l|}{ Cost model } \\
\hline Dump trucks & Distance to disposal & Triangle & 3 & 5 & 20 \\
\hline Sweeping & Cost per kilometre & Uniform & $\$ 45$ & $\$ 68$ & $\$ 90$ \\
\hline
\end{tabular}

${ }^{\mathrm{a}}$ Description of various statistical distributions used for Monte Carlo modelling available at http://www.palisade.com/models/RISKDistributions.asp

\section{Clean-up duration}

Clean-up operation durations for both distal eruption scenarios are likely to last longer than one week, but could potentially continue for months in less than favourable conditions (e.g., limited dump truck availability, key dump truck route closures or limitations; Table 6). The duration could also be prolonged if resources from Auckland are redistributed to other areas experiencing a higher level of impact.

The duration estimates are markedly different between the two local scenarios, as was the case for the cost estimates (Table 6). In particular, clean-up of zone 4 of the L1 eruption scenario could take years, whereas the same zone of the L2 eruption scenario is unlikely to exceed one year.
Further work is required here to understand how damage to the built environment will influence clean-up duration, a factor that has not been considered here.

\section{Disposal sites}

The volumes each disposal site will have to manage in each modelled scenario are presented in Fig. 8. As our model designates a disposal site based on shortest trip duration, $\mathrm{D}_{14}$ does not receive any tephra because it is located within a cluster of disposal sites (with $\mathrm{D}_{13}$ and $D_{15}$ ). This means that traffic from the north of the cluster will travel to $\mathrm{D}_{13}$, and traffic to the south of the cluster will travel to $D_{15}$, meaning that $D_{14}$ is never the shortest travel time from any meshblock. 
Table 5 The surfaces requiring tephra removal for an optimised clean-up and total tephra volume removed. $Z=$ removal zone defined in this study

\begin{tabular}{|c|c|c|c|c|c|c|}
\hline \multirow[t]{2}{*}{ Scenario } & \multicolumn{4}{|c|}{ Surfaces cleaned } & \multirow[t]{2}{*}{ Area impacted $\left(\mathrm{km}^{2}\right)$} & \multirow{2}{*}{$\begin{array}{l}\text { Tephra volume } \\
\text { removed }\left(\mathrm{m}^{3}\right)\end{array}$} \\
\hline & Roads & Roofs & Other impervious surfaces & Vegetated areas & & \\
\hline Thin distal & $\sqrt{ }$ & & & & 808 & $3.6 \times 10^{4}$ \\
\hline Thick distal & $\sqrt{ }$ & $\sqrt{ }$ & $\sqrt{ }$ & & 808 & $2.2 \times 10^{6}$ \\
\hline \multicolumn{7}{|l|}{ L1 } \\
\hline $\mathrm{Z1}$ & $\sqrt{ }$ & & & & 65 & $1.3 \times 10^{4}$ \\
\hline $\mathrm{Z2}$ & $\sqrt{ }$ & $\sqrt{ }$ & $\sqrt{ }$ & & 69 & $3.1 \times 10^{5}$ \\
\hline $\mathrm{Z3}$ & $\sqrt{ }$ & $\sqrt{ }$ & $\sqrt{ }$ & $\sqrt{ }$ & 12 & $8.6 \times 10^{5}$ \\
\hline Z4 & $\sqrt{ }$ & $\sqrt{ }$ & $\sqrt{ }$ & $\sqrt{ }$ & 58 & $5.9 \times 10^{7}$ \\
\hline \multicolumn{7}{|l|}{ L2 } \\
\hline $\mathrm{Z1}$ & $\sqrt{ }$ & & & & 56 & $1.5 \times 10^{4}$ \\
\hline Z2 & $\sqrt{ }$ & $\sqrt{ }$ & $\sqrt{ }$ & & 17 & $9.6 \times 10^{4}$ \\
\hline Z3 & $\sqrt{ }$ & $\sqrt{ }$ & $\sqrt{ }$ & $\sqrt{ }$ & 13 & $1.3 \times 10^{6}$ \\
\hline Z4 & $\sqrt{ }$ & $\sqrt{ }$ & $\sqrt{ }$ & $\sqrt{ }$ & 12 & $6.8 \times 10^{6}$ \\
\hline
\end{tabular}

In the distal scenarios, almost all disposal sites are utilised due to the wide distribution of tephra across the Auckland metropolitan area. Conversely, for the local scenarios only a few sites are used, as the tephra is less widely distributed (fewer meshblocks affected). As a consequence, these disposal sites must accept much higher volumes of tephra than the others. Without specific assessments of each disposal site, it is difficult to determine the volumetric capacity of each. Such an assessment is beyond the scope of this work, but we have included the surface area of each disposal site as reported in Dolan et al. (2003) for comparison between the volume each disposal site will need to take, and the area it has to use (Fig. 8).

\section{Critique of model}

Sensitivity analysis

We undertook a sensitivity analysis to determine the parameters that most strongly influence the model outputs. This can assist with identifying priorities for refining the model and assessing model robustness.

The street sweeper clean-up equation is very sensitive to the efficiency of the sweeper trucks in removing tephra from road surfaces (Fig. 9). This is an important consideration because officials tasked with tephra cleanup often comment that clean-up operations took longer than expected due to multiple sweeper runs being required on roads (Blong 1984; Magill et al. 2013; Hayes et al. 2015). Refining this value is difficult because of the variety of factors that influence sweeper efficiency (e.g.,

Table 6 Summary of optimised clean-up model outputs

\begin{tabular}{|c|c|c|c|c|c|c|c|}
\hline \multirow{2}{*}{\multicolumn{2}{|c|}{ Scenario }} & \multicolumn{3}{|l|}{ Duration (days) } & \multicolumn{3}{|c|}{ Cost (NZ\$ million) } \\
\hline & & 10th percentile & 90th percentile & 50th percentile & 10th percentile & 90th percentile & 50th percentile \\
\hline \multicolumn{2}{|c|}{ Thin distal (roads) } & 10 & 86 & 32 & 0.6 & 1.1 & 0.9 \\
\hline \multicolumn{2}{|c|}{ Thick distal } & 40 & 251 & 99 & 13.4 & 25.6 & 17.8 \\
\hline \multirow[t]{5}{*}{ L1 } & $\mathrm{Z1}$ & 3 & 27 & 10 & 0.2 & 0.3 & 0.3 \\
\hline & $\mathrm{Z2}$ & 2 & 12 & 5 & 1.8 & 3.5 & 2.4 \\
\hline & $\mathrm{Z3}$ & 2 & 9 & 4 & 5 & 10 & 6.8 \\
\hline & Z4 & 164 & 916 & 404 & 348 & 670 & 465 \\
\hline & All areas & 171 & 964 & 423 & 355 & 684 & 475 \\
\hline \multirow[t]{5}{*}{ L2 } & $\mathrm{Z1}$ & 3 & 13 & 6 & 0.1 & 0.2 & 0.1 \\
\hline & Z2 & 0 & 2 & 1 & 0.6 & 1.1 & 0.8 \\
\hline & $\mathrm{Z3}$ & 3 & 13 & 6 & 8 & 14 & 10 \\
\hline & Z4 & 54 & 346 & 136 & 41 & 78 & 54 \\
\hline & All areas & 60 & 374 & 149 & 49.7 & 93.3 & 64.9 \\
\hline
\end{tabular}




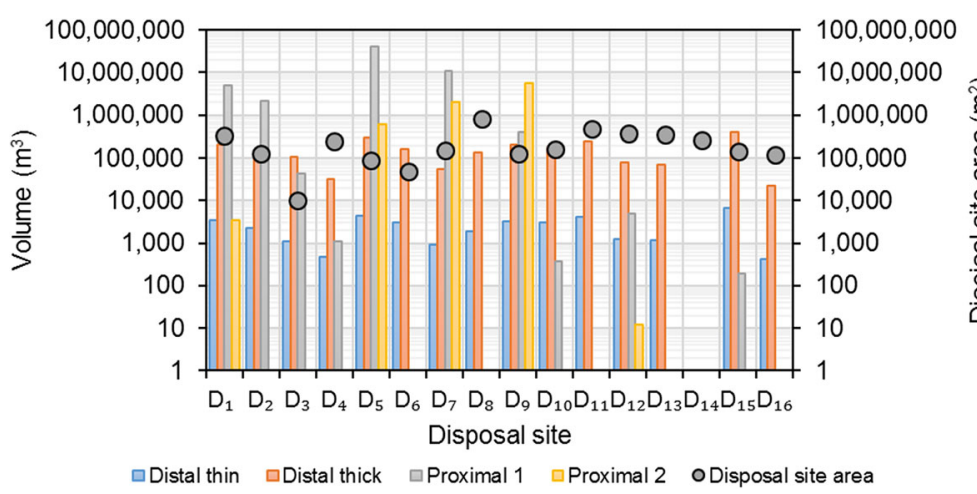

Fig. 8 Volumes of tephra to individual disposal sites (see Fig. 2 for locations of disposal sites)

grain size distribution, sweeper types, rainfall, road type, maintenance of sweepers). However, one variable that can be refined with further consultation is the number of available sweeper trucks.

Similarly, the dump truck clean-up duration equation is heavily influenced by the number of available trucks, especially the dump trucks that can carry larger volumes (Fig. 10). This is because they reduce the number of required trips to remove tephra. The equation is also sensitive to the hours per day that trucks can travel to and from disposal sites. The remaining parameters (e.g., unloading time, bucket cycle time) have a minor influence on sensitivity.

The cost equation is much simpler than the duration models, and for this reason is only sensitive to either the cost per kilometre (for street sweeping operations) or the distance that dump trucks have to travel to disposal sites. However, the costs assessed in our model only includes the transportation and disposal site operational costs, and as such should be considered minima.

\section{Comparison with real world tephra clean-up operations}

To compare our tephra removal volume outputs with real-world tephra clean-up operations, we use the method outlined in Hayes et al. (2015) for quantifying

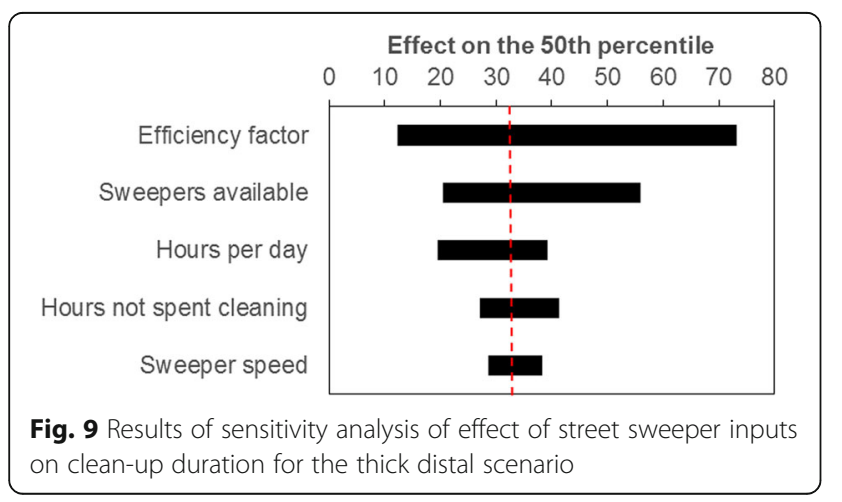

the total tephra accumulation as $\mathrm{m}^{3}$ per $\mathrm{km}^{2}$ in an urban area. We then selected a number of case studies from Hayes et al. (2015) based on similar tephra fall accumulations to our modelled scenarios (within $\pm 25 \%$ ) (Fig. 11). While our model appears to overestimate the proportion of the total deposit removed when compared with global case studies, we consider these outputs reasonable in light of uncertainties associated with the reported data in Hayes et al. (2015).

\section{Tephra clean-up complexities}

In our effort to develop a useful model for clean-up operation requirements, we found it necessary to make a number of assumptions and simplifications. These assumptions and simplifications are summarised in Table 7 and discussed in the following subsections.

\section{Uncertainties relating to removal volumes}

In this study we have used thresholds to determine the point at which different scales of clean-up operation are initiated. Although these thresholds are informed by previous work in Hayes et al. (2015), the exact tephra thickness at which municipal clean-up workers or contractors hired by municipal authorities will assist private property owners with clean-up and removal is uncertain, and may be inconsistent even across a single response. In this work

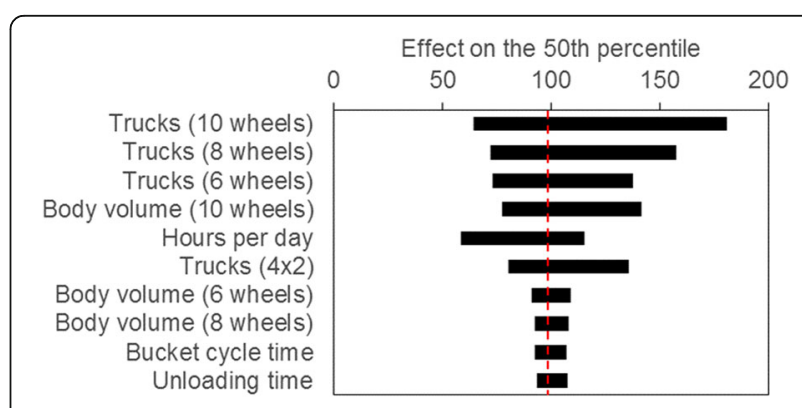

Fig. 10 Results of sensitivity analysis of effect of dump truck inputs on clean-up duration for the thick distal scenario 


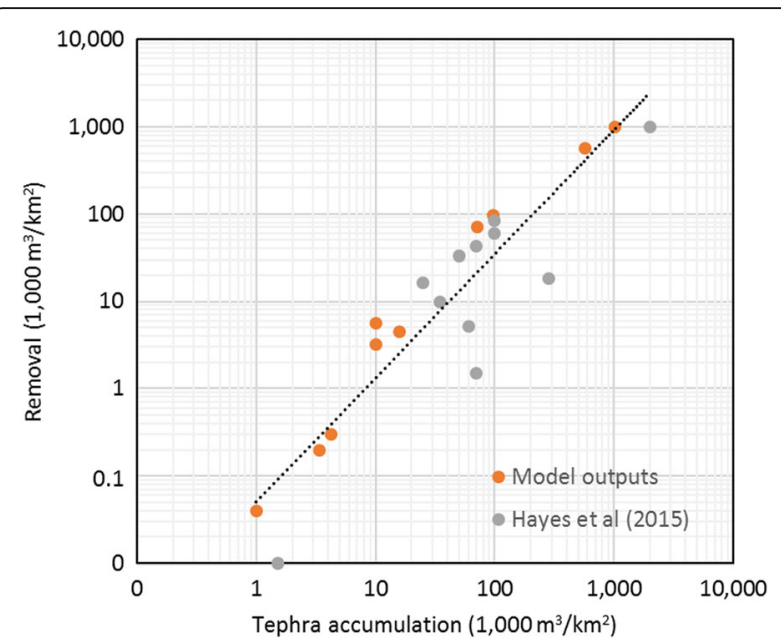

Fig. 11 Comparison of model outputs to estimates by Hayes et al. (2015) of proportion of tephra removed $\left(R^{2}=0.8\right)$

we have assumed $10 \mathrm{~mm}$ is the response threshold. In reality the boundary would likely be 'fuzzy' with decisions regarding where to send municipal clean-up resources partially based on where impacts are occurring and actions required to restore functionality to critical services. Therefore, whilst some property owners might receive assistance from municipal authorities, others will be reliant on themselves, hired contractors, or volunteers.

Physical properties of the deposits could have an influence on clean-up. The bulk density of tephra could have an influence of the total volume of material that is disposed of and the disposal site requirements. Here we have used deposit thickness to estimate volume, but thickness of deposits can naturally compact up to $50 \%$ within just a few days and could further compact during the transportation in trucks, which would reduce the volume of material that is disposed (Blong et al. 2011; Engwell et al. 2013; Hayes et al. 2015). Further, the surge deposits are likely to be relatively hot, which could create an issue around accessibility and clean-up of those areas in the short term.

Illegal dumping of waste products following disasters is a common occurrence, which can add to volumes of material that must be dealt with by municipal authorities (Brown et al. 2011a; Petersen 2004). Property owners dumping tephra on roads or in gutters has in the past led to infiltration of the storm water system, requiring extensive and costly removal operations (Craig et al. 2016; Hayes et al. 2015). Such activity would add to the duration and cost of clean-up operations.

We have concentrated on the clean-up and removal of tephra deposits. However, in areas impacted by base surges, it is probable that building debris will be mixed with the deposits due to damaging surge impact and infiltration into buildings (Baxter et al. 2005; Spence et al.
2007). This will increase the volume of material requiring removal and might require that waste is sorted before disposal. Anecdotal accounts suggest sorting disaster waste can present complications (e.g., hazardous wastes handling) and can prolong clean-up operations due to double-handling the waste (e.g., taking it to a sorting site and then moving to a permanent disposal site) or sorting material in situ before transportation to disposal sites (Brown et al. 2011a). This could increase clean-up operation duration and costs.

\section{Potential influences on hauling times}

Another factor that could lead to underestimating cleanup duration is the impact of vehicle traffic on hauling times. Although including traffic information within the clean-up model could be beneficial, it is challenging to determine the post-eruption regulation of traffic, particularly for a local eruption within the AVF. This is because reductions in visibility and traction (due to either in situ or remobilised tephra) have previously resulted in reduced speeds or closed roads (Blong 1984; Wilson et al. 2012, 2014; Blake DM, Wilson TM, Cole JW, Deligne NI, Lindsay JM: Impact of volcanic ash on road and airfield surface skid resistance. Submitted; Blake, DM, Wilson TM, Stewart C: Visibility in airborne volcanic ash: considerations for surface transport using a laboratorybased method. Submitted), changes in traffic routing due to detours are probable (Blake DM, Deligne NI, Wilson TM, Lindsay JM, Woods R: Investigating the consequences of urban volcanism using a scenario approach II: Insights into transportation network damage and functionality. Submitted; Deligne et al. 2015), and potential post eruption traffic volumes are unknown due to the possibility of an evacuated population (Deligne NI, Fitzgerald RH, Blake DM, Davies AJ, Hayes JL, Stewart C, Wilson G, Wilson TM, Kennedy B, Carneiro R, Muspratt S, Woods R: Investigating the consequences of urban volcanism using a scenario approach I: Development and application of a hypothetical eruption in the Auckland Volcanic Field, New Zealand, Submitted).

Hauling times could also be increased due to bottlenecks in resource availability. For example, if there are not enough loaders or diggers to fill dump trucks queues could form at pickup points. For simplicity, we have assumed that the loader/digger resources will be scaled appropriately for the number of dump trucks that are used; this could be lead to us underestimating the duration of clean-up activities.

\section{Complexities relating to disposal sites}

Most disposal sites will require some initial works to prepare the site for accepting tephra. Such works might include: site design, establishing access for trucks, and building spotting towers. In addition, remediation of 
Table 7 Summary of model assumptions and simplifications on model outputs

\begin{tabular}{|c|c|c|c|}
\hline \multirow[t]{2}{*}{ Assumption/simplification } & \multicolumn{3}{|c|}{ Implication for model output } \\
\hline & Under estimation & Over estimation & Negligible \\
\hline \multicolumn{4}{|l|}{ Removal volumes } \\
\hline No other waste streams (e.g., construction/demolition) & $x$ & & \\
\hline No clean-up within $500 \mathrm{~m}$ of vent due to level of destruction & $x$ & & \\
\hline Remobilisation of deposits not considered & $x$ & & \\
\hline Potential for deposits to infiltrate storm water system not considered & & $x$ & \\
\hline $100 \%$ of tephra on surfaces removed & & $x$ & \\
\hline Asset sub-categories not considered (e.g., building/road typologies) & & $x$ & \\
\hline Long lasting eruption/multiple fallout events & $x$ & $x$ & \\
\hline \multicolumn{4}{|l|}{ Clean-up duration } \\
\hline Clean-up vehicles can operate on tephra covered roads & $x$ & & \\
\hline Traffic not considered & $x$ & & \\
\hline Time moving tephra from properties to pick-up points not considered & & & $x$ \\
\hline Potential restrictions on truck routes to disposal sites not considered & $x$ & & \\
\hline Worker breaks and vehicle maintenance not considered & $x$ & & \\
\hline Shortest trip duration to contingency plan disposal sites must be used & $x$ & & \\
\hline Duration for scoping and planning not considered & & & $x$ \\
\hline Disposal site operational capacity not considered & $x$ & & \\
\hline Street sweeper travel inefficiencies (e.g., moving around parked cars) & $x$ & & \\
\hline Assume rational operators within system & $x$ & & \\
\hline Heavy machinery quantity scaled for truck fleet requirements & $x$ & & \\
\hline Experience level of clean-up managers not considered & $x$ & & \\
\hline Remobilisation not considered & $x$ & & \\
\hline Rainfall not considered & $x$ & $x$ & \\
\hline Time it takes material to accumulate not considered & $x$ & & \\
\hline \multicolumn{4}{|l|}{ Clean-up cost } \\
\hline Existing solid waste and disaster waste contracts & $x$ & $x$ & $x$ \\
\hline Coordination and volunteerism costs & $x$ & & \\
\hline Business disruption costs & $\mathrm{x}$ & & \\
\hline No post-disaster price escalation & $x$ & & \\
\hline
\end{tabular}

sites following disposal activities is important to prevent remobilisation of the deposits, and if necessary allowing the site to be re-used for future activity (Hayes et al. 2015). The costs and duration of time associated with establishment and remediation of a disposal site are difficult to quantify and are likely to be site specific and based on local waste disposal and environmental regulations.

A further influence on clean-up duration is disposal site operational capacity (truck visits per day) due to bottlenecks of trucks getting into disposal sites, or regulations for allowable truck visits per day. For example, to manage the negative effects on traffic flow and noise it is possible that restrictions will be placed on the allowable number of truck visits per day or hour. In the model outputs presented in this paper we have not placed any restrictions on disposal sites as it is challenging to ascertain an appropriate restriction without site specific assessment of each disposal site. Such an assessment is beyond the scope of this work. However, our model is flexible enough to allow for such a consideration in the future. The implication for not considering disposal site limitations is that our model outputs for duration and cost are likely to be underestimated.

\section{Uncertainties relating to clean-up cost}

We adjust the cost rates from Johnston et al. (2001) for inflation and use them within our model. The Johnston et al. (2001) values are a first order estimate and subject to a number of uncertainties and complexities associated with clean-up operation costs. In particular, it is difficult to accurately constrain costs such as volunteer and 
labourer coordination, resource procurement (e.g., purchased, hired, or donated), and machinery wear and tear due to infiltration by volcanic ash into air intake filters (Brown et al. 2011a; Hayes et al. 2015). In many cases, such aspects will be context specific. Further, disaster clean-up is largely a contracted solid waste management process that includes collection, transport, and disposal with solid waste companies contracting their services at varying rates (Brown et al. 2011a). Therefore, individually negotiated contracts between both private and public organisations can influence the total cost of clean-up to a municipal authority. For example, in Christchurch, clean-up of liquefaction ejecta following the 2010-2011 earthquakes was conducted by using prior flood cleanup arrangements by contracting two companies as per emergency conditions within their existing road maintenance contracts (Villemure et al. 2012). These contractors then scaled up their activities to meet the demand by hiring a number of subcontractors as part of their clean-up activities (Villemure et al. 2012).

Clean-up costs can also be influenced by market forces, but the relationship is not straight-forward. Demand surge has been observed following large scale disasters where costs rapidly inflate by $10-50 \%$ comparatively with predisaster costs (Döhrmann et al. 2013; Hallegatte and Ghil 2008; Olsen and Porter, 2011). However, costs can also decrease due to increased competition from a large number of contractors descending on an affected area (Brown et al. 2016). There is also precedent where contractors have agreed to conduct disaster clean-up activities on an 'at cost' basis rather than at market rates (e.g., Victorian bushfires; Brown et al. 2011b). Additionally, recycling and reuse of materials can offset clean-up costs and this is an area of potential for clean-up of tephra (Brown et al. 2016; Hayes et al. 2015). For example, following the Kelud 2014 eruption in Indonesia, clean-up activities in Kediri Regency, were at least partially offset by reusing the volcanic deposits for construction material (Blake et al. 2015).

Therefore, the cost of clean-up is context specific and requires consideration of factors such as the type of tephra, assets exposed, and prior contractual arrangements. Thus, although our model provides a good first order approximation, we acknowledge that there is a high level of uncertainty associated with assessing tephra clean-up costs.

Other costs may also result directly or indirectly from a tephra (or any solid disaster waste) clean-up. For example, some businesses may be forced to close or change operations whilst clean-up activities are conducted, such as by staff or by private contractor. This could lead to both loss of business activity as well as direct costs from the clean-up. Exactly how these costs are met is likely to be context specific to the affected region. For example, some governments might provide economic relief packages such as subsidies or grants to offset the effects of clean-up (Tanikawa et al. 2014), or through insurance and other risk transfer mechanisms (as would be the case in Auckland, in a New Zealand context). Assessment of these costs is beyond the scope of this paper, but is an important area of future research.

\section{Prioritisation of clean-up activities}

Cities that conduct tephra clean-up operations will sometimes prioritise the clean-up of areas or assets to reduce current impacts, foster recovery and/or maximise clean-up operation efficiency (Hayes et al. 2015). For example, Washington State communities affected by tephra from Mt. St. Helens in 1980 (USA) prioritised downtown central business districts and important arterial roads for clean-up (Kartez and Kelley 1980). Cleanup of central business district and other touristic areas took place in Bariloche, Argentina, following tephra fall from 2011 eruption of Cordón-Caulle (Wilson et al. 2013). In comparison, others towns (e.g., Moscow, Washington after Mt. St. Helens 1980 eruption) which have experienced tephra fall have prioritised clean-up by working systematically across a built up area (Hayes et al. 2015; Kartez and Kelley 1980). In this paper, we have chosen not to implement prioritisation, as we consider this to be a model customisation to be made in consultation with local decision makers and (ideally) communities. Our clean-up model has been utilised within a detailed scenario planning exercise looking at critical infrastructure impact from an Auckland Volcanic field eruption (Deligne et al. 2015). In the scenario planning exercise infrastructure and emergency managers prioritised clean-up of Auckland's motorways to ensure a north-south transport corridor was maintained to aid transportation functionality for the city (see Blake DM, Deligne NI, Wilson TM, Lindsay JM, Woods R: Investigating the consequences of urban volcanism using a scenario approach II: Insights into transportation network damage and functionality. Submitted).

When an eruption and subsequent tephra fall occurs municipal authorities are faced with uncertainty about how long an eruptive sequence might last for. In the context of tephra clean-up this is challenging as it is preferable to not clean surfaces multiple times in quick succession (Hayes et al. 2015). Such circumstances have led to some communities (e.g., Catania following a 2002 eruption of Mt. Etna; Barnard 2004) delaying clean-up operations until they have greater confidence that further tephra fall events are unlikely (Hayes et al. 2015). However, taking this approach can lead to unnecessary impacts such as tephra infiltrating and clogging storm water systems, so striking a balance is optimal but difficult (Wilson et al. 2012).

There is evidence that a community's tolerance to an ashy environment can evolve depending on how they 
adapt to exposure to multiple and regular tephra fall events (Sword-Daniels et al. 2014), so following longlasting volcanic eruptions it is possible that thresholds of tephra fall volume or thicknesses that trigger clean-up operations may change. The amount of change is difficult to establish, but could potentially be linked to forecasts from volcanologists about the likelihood of future tephra fall events and land use type of the affected area.

Previous eruptions within the AVF have exhibited complex multi-phase eruption sequences with an initiating phreatomagmatic phase followed by scoria cone development and lava flows (Kereszturi et al. 2013). Local eruptions within the AVF have the potential to last for years but it is most probable that any explosive phases will last on the order of days to a few months (Kereszturi et al. 2013). We have previously applied our clean-up model in a complex multi-phase eruption scenario detailed in Deligne et al. (2015), of which our L2 eruption scenario is based on. The results presented in Deligne et al. (2015) demonstrated that clean-up of affected areas from the month long eruption scenario was constrained by evacuation/exclusions zones likely to be in place. Furthermore, volcanism within the AVF has exhibited considerable variability in the eruption location, eruption sequence, eruption duration, and erupted volume (Kereszturi et al. 2013). The scenarios presented here are used for the purpose of demonstrating the application of our tephra clean-up model and are not intended as a forecast. We acknowledge that our model outputs could be very different given another eruption location, sequence, duration (e.g., multiple sporadic phases), and eruptive volume.

\section{Model refinement}

Some of the limitations presented here could be remedied with more information (e.g., inclusion of traffic modelling, inventory of likely clean-up resources, hours per day of operation). However, some information will always be difficult to quantify, such as the impact that tephra remobilisation will have on clean-up operations, due to the uncertainty of variables such as wind, rain, and grain size.

The most feasible methods by which this model could be refined are:

- Testing the efficiency of different types of street sweepers at removing fine-grained tephra deposits from road surfaces under different conditions (e.g., wet or dry tephra deposits). Similar studies have been conducted in the USA for general roadside maintenance (Selbig and Bannerman 2007);

- Establishing a more detailed inventory of resources (e.g., disposal site capacity, truck type and quantity, loaders quantity) that are likely to be available in a post-disaster environment;
- A better understanding of the costs associated with tephra clean-up operations. In particular: how procurement of resources and services will be made, contractor payment structures (i.e., a lump sum for entire clean-up, or a flat rate on a per hour, volume, or tonnage basis).

- Incorporating costs to establish and remediate disposal sites, as this will influence cost-benefit of how many disposal sites will be utilised (e.g., one big site or many small sites); and

- Determining operational capacity and design of disposal sites (truck visits per day).

\section{Model uses for response and recovery planning}

We strongly encourage future volcanic impact and risk assessments to incorporate consideration of clean-up requirements. Our model could be applied either as a stand-alone geospatial analysis or incorporated into risk assessment software packages (e.g., RiskScape). The model presented here provides valuable information about the likely impact that clean-up operations will have on urban environments blanketed with tephra. The following information can inform volcanic eruption response and recovery plans:

- Estimates of total tephra volume to be removed can be used to place constraints on disposal site selection and understand resource requirements (e.g., number of dump trucks required).

- Potential costs of clean-up operations; this, along with other costs associated with a volcanic eruption (e.g., evacuation, building damage), can help place the economic impact of volcanic eruptions in context with other perils such as earthquakes and hurricanes. This helps with policy-level decision making (e.g., land use decisions) and prioritisation of resources and funding.

- Duration of clean-up operations will help authorities prioritise areas of response that can be restored close to full functionality quickly, versus areas that will require a long recovery process. This will inform resource needs and allocation (e.g., dump trucks, volunteer workforce).

- Duration of clean-up also assists with assessing the appropriateness of disposal site locations. Disposal sites located far away from impacted areas will increase clean-up duration due to hauling times.

- Sectors such as air and road transportation rely on clean-up before they can regain full functionality. Our model helps identify potential outage timeframes for these sectors (e.g., Deligne et al. 2015).

\section{Conclusions}

Tephra clean-up operations are a critical aspect of emergency response and socioeconomic recovery from volcanic 
eruptions, and should be included within volcanic impact and risk assessments of urban environments. This study presents a scalable and adaptable method for modelling tephra clean-up operations conducted by municipal authorities in urban environments. The model is informed by published information on tephra clean-up operations from volcanic eruptions and urban areas around the world. The model determines the potential volume of tephra to be removed, and the cost and duration of cleanup operations. Model outputs of removal volume, cleanup duration and cost yield useful information for response and recovery planning purposes. Some potential uses of this information include policy-level decision making, operational level resource requirements and prioritisation, and evaluation of current response plans.

Model outputs should be considered as estimates only, as clean-up operations are complex processes influenced by variables difficult to precisely quantify such as tephra remobilisation and sweeper truck inefficiencies. Sensitivity analysis suggests that results could be refined by incorporating a more detailed understanding of the quantity and type of dump trucks available for use in clean-up operations.

We applied the model to four tephra clean-up scenarios for Auckland, New Zealand: thin $(1 \mathrm{~mm})$ and thick $(10 \mathrm{~mm})$ distal eruptions and two local Auckland Volcanic Field eruptions. Model outputs appear reasonable when compared to real-world case studies of tephra fall clean-up in urban environments, suggesting that our model is both scalable and adaptable to other urban contexts around the world.

\section{Endnotes}

${ }^{1}$ Origin-destination cost matrix modelling within ArcGIS 10.

${ }^{2}$ We did this by first adjusting 2013 USD to 2015 USD to account for inflation. This was done by taking the 2013 Consumer Price Index (CPI) and determining the percentage difference with the 2015 CPI based on information from United States Department of Labor (2016). This yielded a rate of inflation between 2013 USD and 2015 USD of $1.9 \%$. Then, 2015 USD was adjusted to NZD by taking the maximum, minimum, and median USD to NZD monthly average exchange rate values from Reserve Bank of New Zealand (2016b).

\footnotetext{
Acknowledgements

Many thanks to Auckland Council for feedback on a number of model inputs. We thank Tim Davies and David Johnston for providing valuable input to earlier versions of this manuscript. We thank two anonymous reviewers for providing useful comments which greatly enhanced the quality of this paper. We also thank Auckland Council and the Riskscape programme (GNS Science/NIWA) for making a number of data sets available.
}

\section{Funding}

We wish to acknowledge DEVORA (Earthquake Commission, Auckland Council, GNS Science) (JH, TW, NID), Mason Trust (JH), Ministry of Business,
Innovation, and Employment Natural Hazards Research Platform Contract C05X0804 (TW, JC) and GNS Science Core Research Funding (NID) for funding support.

\section{Authors' contributions}

$\mathrm{JLH}$ wrote the paper and developed the tephra clean-up model, TMW, NID, JC, and $\mathrm{MH}$ provided input for the tephra clean-up model, the overall structure and drafting of the paper. All authors read and approved the final manuscript.

\section{Competing interests}

The authors declare that they have no competing interests.

\section{Author details}

${ }^{1}$ Department of Geological Sciences, University of Canterbury, Christchurch, New Zealand. ${ }^{2}$ GNS Science, Lower Hutt, New Zealand. ${ }^{3}$ Department of Civil and Natural Resources Engineering, University of Canterbury, Christchurch, New Zealand.

Received: 4 July 2016 Accepted: 19 December 2016

Published online: 06 January 2017

\section{References}

Auckland Civil Defence Emergency Management (ACDEM). Auckland Volcanic Contingency Plan. Auckland: Auckland Council; 2015.

Auckland Council. Auckland Council waste assessment. Auckland: Auckland Council; 2011.

Auckland Council. Proposed Auckland Unitary Plan Decisions. 2016. http:// unitaryplan.aucklandcouncil.govt.nz/pages/plan/Book.aspx?exhibit= ACDecision. Accessed on 12 Nov 2016.

Barnard ST. Results of a reconnaissance trip to Mt. Etna, Italy: the effects of the 2002 eruption of Etna on the province of Catania. Bull N Z Soc Earthq Eng. 2004;37(2):47-61.

Baxter PJ, Boyle R, Cole P, Neri A, Spence R, Zuccaro G. The impacts of pyroclastic surges on buildings at the eruption of the Soufriere Hills volcano, Montserrat. Bull Volcanol. 2005;67(4):292-313. doi:10.1007/s00445-004-0365-7.

Bebbington MS, Cronin SJ. Spatio-temporal hazard estimation in the Auckland Volcanic Field, New Zealand, with a new event-order model. Bull Volcanol. 2011;73:55-72. doi:10.1007/s00445-010-0403-6.

Blake DM, Wilson TM, Gomez C. Road marking coverage by volcanic ash: an experimental approach. Environ Earth Sci. 2016;75:1348. doi:10.1007/s12665016-6154-8.

Blake DM, Wilson G, Stewart C, Craig, H, Hayes JL, Jenkins SF, Wilson TM. Horwell CJ, Daniswara R, Ferdiwijaya D, Leonard GS, Hendrasto M, Cronin S. Impacts of the 2014 eruption of Kelud volcano, Indonesia, on infrastructure, utilities, agriculture and health. GNS Science Report 2015/15. 2015

Blong R. Volcanic hazards: a sourcebook on the effects of eruptions. Australia: Academic; 1984.

Blong R, Enright N. Preservation of thin tephras. 2011. Unpublished manuscript. From https://www.researchgate.net/publication/267202887_PRESERVATION_ OF_THIN_TEPHRAS. Accessed on 28 Sept 2016.

Brown C, Milke M. Recycling disaster waste: Feasibility, method and effectiveness. Resour Conserv Recycl. 2016;106:21-32. doi:10.1016/j.resconrec.2015.10.021.

Brown C, Milke M, Seville E. Disaster waste management: a review article. Waste Manag. 2011a;31:1085-98. doi:10.1016/j.wasman.2011.01.027.

Brown C, Milke M, Seville E. Disaster waste management case study: 2009 Victorian Bushfires, Australia. Australian J Emerg Manag. 2011b;26:17-22.

Campbell JF, Langevin A. Operations management for urban snow removal and disposal. Transp Res A Policy Pract. 1995;29(5):359-70. doi:10.1016/09658564(95)00002-6.

City and County of San Francisco. San Francisco disaster debris plan, appendix to ESF \#3: public works and engineering annex of the San Francisco emergency response plan. San Francisco: City and County of San Francisco; 2011.

City of Miami. City of Miami debris management plan. Miami: The City of Miami; 2008.

Comes T, Van De Walle B. Measuring disaster resilience: The impact of hurricane sandy on critical infrastructure systems. In: Hiltz SR, Pfaff MS, Plotnik L, Shih PC (eds) ISCRAM 2014 Conference Proceedings - 11th International Conference on Information Systems for Crisis Response and Management, University Park, Pennsylvania, USA. May 2014. 2014.

Cook TM, Alprin BS. Snow and ice removal in an urban environment. Manag Sci. 1976;23(3):227-34. doi:10.1287/mnsc.23.3.227. 
Craig H, Wilson TM, Stewart C, Outes V, Villarosa G, Baxter P. Impacts to agriculture and critical infrastructure in Argentina after ashfall from the 2011 eruption of the Cordón Caulle volcanic complex: an assessment of published damage and function thresholds. J Appl Volcanol. 2016;5(1):7. doi:10.1186/s13617-016-0046-1.

Deligne NI, Blake D, Davies A, Grace E, Hayes J, Potter S, Stewart, C. Wilson G, Wilson TM. Economics of Resilient Infrastructure Auckland Volcanic Field scenario. ERI Res Rep. 2015; 2015/03.

Döhrmann D, Gürtler M, Hibbeln M. An econometric analysis of the demand surge effect. Zeitschrift fur die gesamte Versicherungswiss. 2013;102:537-53. doi:10.1007/s12297-013-0239-1.

Dolan L, Wilson C, Johnston DM. Potential volcanic ash disposal sites. GNS Client Report 2003; 2003/75.

Dupree C. Street sweeping: an effective non-structural Best Management Practice (BMP) for improving stormwater quality in Nelson?, NIWA Client Report. 2011; HAM2011-043.

Earthquake Commission. Get help after volcanic eruption. 2015. http://www.eqc. govt.nz/get-help-now/help-volcanic-eruption. Accessed 26 Aug 2015.

Engwell S, Sparks R, Aspinall W. Quantifying uncertainties in the measurement of tephra fall thickness. J Appl Volcanol. 2013;2:5. doi:10.1186/2191-5040-2-5.

Fitzgerald RH, Dohaney J, Hill D, Wilson TM, Kennedy B, Lindsay J. Teaching volcanic monitoring and hazard mitigation within an urban area: A volcanic hazards simulation of the Auckland Volcanic Field. GNS Science Report 2014/ 70. 2016.

Green RM, Bebbington MS, Cronin SJ, Jones G. Automated statistical matching of multiple tephra records exemplified using five long maar sequences younger than 75 ka, Auckland, New Zealand. Quat Res. 2014;82(2):405-19. doi:10.1016/ j.yqres.2014.06.004.

Hallegatte S, Ghil M. Natural disasters impacting a macroeconomic model with endogenous dynamics. Ecol Econ. 2008;68:582-92. doi:10.1016/j.ecolecon. 2008.05.022.

Harp EL, Jibson RW. Landslides triggered by the 1994 Northridge, California, earthquake. Bull Seismol Soc Am. 1996;86(1B):S319-32.

Hayes JL, Wilson TM, Magill C. Tephra fall clean-up in urban environments. J Volcanol Geotherm Res. 2015;304:359-77. doi:10.1016/j.jvolgeores.2015.09.014.

Hopkins JL, Millet M-A, Timm C, Wilson CN, Leonard GS, Palin MJ, Neil H. Tools and techniques for developing tephra stratigraphies in lake cores: a case study from the basaltic Auckland Volcanic Field, New Zealand. Quat Sci Rev. 2015;123:58-75. doi:10.1016/j.quascirev.2015.06.014.

Horwell CJ, Baxter PJ. The respiratory health hazards of volcanic ash: a review for volcanic risk mitigation. Bull Volcanol. 2006;69(1):1-24. doi:10.1007/s00445-006-0052-y.

Horwell CJ, Fenoglio I, Vala Ragnarsdottir K, Sparks RSJ, Fubini B. Surface reactivity of volcanic ash from the eruption of Soufrière Hills volcano, Montserrat, West Indies with implications for health hazards. Environ Res. 2003;93(2):202-15. doi:10.1016/S0013-9351(03)00044-6.

Howes T, Cheesebrough T. Infrastructure impact and recovery following the 2010 2011 earthquakes in Christchurch, New Zealand. Proc Ins Civil Eng. 2013;166:57-64.

Hurst T, Smith W. Volcanic ashfall in New Zealand probabilistic hazard modelling for multiple sources. N Z J Geol Geophys. 2010;53(1):1-14. doi:10.1080/ 00288301003631129 .

Jenkins S, McAneney J, Magill C, Blong R. Regional ash fall hazard II: Asia-Pacific modelling results and implications. Bull Volcanol. 2012;74:1713-27. doi:10. 1007/s00445-012-0628-7.

Jenkins SF, Wilson TM, Magill CR, Miller V, Stewart C, Marzocchi W, Boulton M. Volcanic ash fall hazard and risk: Technical Background Paper for the UNISDR 2015 global assessment report on disaster risk reduction, Global volcano model and IAVCEI. 2014

Johnston DM, Houghton BF, Neall VE, Ronan KR, Paton D. Impacts of the 1945 and 1995-1996 Ruapehu eruptions, New Zealand: an example of increasing societal vulnerability. Geol Soc Am Bull. 2000;112(5):720-6. doi:10.1130/00167606(2000) $112<720:$ IOTARE $>2.0 . C O ; 2$.

Johnston DM, Becker J, Alloway B, Manville V. Auckland engineering lifelines group volcanic ash review part 1, Impacts on lifeline services and collection/disposal issues. Auckland Regional Council Technical Publication No.144. 2001.

Johnston DM, Dolan L, Saunders W, Van Schalkwyk R, Killeen C, Cousins J, Glavovic B, Mclntyre I, Brown C. Disposal of debris during urban earthquakes: Guiding the development of comprehensive pre-event plans, GNS Science report 2009/33. 2009.

Kagoshima City. Overview of the measures against the Sakurajima Volcano. 2013. p. 233.

Kartez JD, Kelley WJ. Emergency planning and the adaptive local response to the Mt. St. Helens eruption. Program in Environmental Science \& Regional Planning, Environmental Research Center. Pullman: Washington State University; 1980. p. 100.
Kereszturi G, Nemeth K, Cronin SJ, Agustin-Flores J, Smith IEM, Lindsay J. A model for calculating eruptive volumes for monogenetic volcanoes Implication for the Quaternary Auckland Volcanic Field, New Zealand. J Volcanol Geotherm Res. 2013;266:16-33. doi:10.1016/j.jvolgeores.2013.09.003.

Kereszturi G, Nemeth K, Cronin SJ, Procter J, Agustin-Flores J. Influences on the variability of eruption sequences and style transitions in the Auckland Volcanic Field, New Zealand. J Volcanol Geotherm Res. 2014;286:101-15. doi:10.1016/j.jvolgeores.2014.09.002.

Kermode L. Geology of the Auckland urban area, scale 1:50 000. Lower Hutt: Institute of Geological and Nuclear Sciences Limited; 1992.

Kobayashi Y. Disasters and the problems of wastes - Institutions in Japan and issues raised by the Great Hanshin-Awaji Earthquake, In: Earthquake Waste Symposium 12-13 June 1995. Osak; 1995.

Labelle A, Langevin A, Campbell JF. Sector design for snow removal and disposal in urban areas. Socio Econ Plan Sci. 2002;36:183-202. doi:10.1016/s0038-0121(01)00024-6.

Lane K, Charles-Guzman K, Wheeler K, Abid Z, Graber N, Matte T. Health effects of coastal storms and flooding in urban areas: a review and vulnerability assessment. J Environ Public Health. 2013;2013:1-13. doi:10.1155/2013/913064.

Magill C, Blong R, McAneney J. VolcaNZ-a volcanic loss model for Auckland, New Zealand. J Volcanol Geotherm Res. 2006;149:329-45. doi:10.1016/j. jvolgeores.2005.09.004.

Magill C, Wilson TM, Okada T. Observations of tephra fall impacts from the 2011 Shinmoedake eruption, Earth. Planets Space. 2013;65(6):677-98. doi:10.5047/ eps.2013.05.010.

Molloy C, Shane P, Augustinus P. Eruption recurrence rates in a basaltic volcanic field based on tephra layers in maar sediments: Implications for hazards in the Auckland volcanic field. Geol Soc Am Bull. 2009;121(11-12):1666-77. doi:10.1130/b26447.1.

Olsen AH, Porter KA What We Know about Demand Surge: Brief Summary. Nat Hazards Rev. 2011;12:62-71. doi:10.1061/(ASCE)NH.1527-6996.0000028.

Perrier N, Langevin A, Campbell JF. A survey of models and algorithms for winter road maintenance. Part I: system design for spreading and plowing. Comput Oper Res. 2006a;33:209-38. doi:10.1016/j.cor.2004.07.006.

Perrier N, Langevin A, Campbell JF. A survey of models and algorithms for winter road maintenance. Part II: system design for snow disposal. Comput Oper Res. 2006b;33:239-62. doi:10.1016/j.cor.2004.07.007.

Petersen M. Restoring waste management following disasters. In: 2004 international conference and student competition on post-disaster reconstruction "planning for reconstruction", april 22-23. 2004. Coventry, UK.

Peurifoy R, Schexnayder CJ. Construction planning, equipment, and methods. Sixth Edition. Boston; 2002.

Reckziegel F, Bustos E, Mingari L, Báez W, Villarosa G, Folch A, Collini E, Viramonte J, Romero J, Osores S. Forecasting volcanic ash dispersal and coeval resuspension during the April-May 2015 Calbuco eruption. J Volcanol Geotherm Res. 2016;321:44-57. doi:10.1016/j.jvolgeores.2016.04.033.

Reserve Bank of New Zealand. B1 Exchange rates \& TWI. 2016. www.rbnz.govt.nz/ statistics/tables/b1. Accessed 9 Jan 2016.

Reserve Bank of New Zealand. Inflation Calculator. 2016. http://www.rbnz.govt.nz/ monetary-policy/inflation-calculator. Accessed 9 Jan 2016.

Runge MG, Bebbington MS, Cronin SJ, Lindsay, JM, Moufti, MR, Sensitivity to volcanic field boundary. J Appl Volcanol. 2015;4:22. doi:10.1186/s13617-015-0040-z.

Schilling JG. Street Sweeping - Report No. 1, State of the Practice, RamseyWashington Metro Watershed District, North St. Paul, Minnesota. 2005.

Selbig WR, Bannerman RT. Evaluation of Street Sweeping as a stormwater quality-management tool in three residential basins in Madison, Wisconsin, U.S. Geological Survey Scientific Investigations Report 20075156. 2007.

Shulters MV, Clifton DG. Mount St. Helens volcanic-ash fall in the bull run watershed, Oregon, March - June 1980, Geological Survey Circular 850-A. 1981.

Spence RJ, Kelman I, Baxter PJ, Zuccaro G, Petrazzuoli S. Residential building and occupant vulnerability to tephra fall. Nat Hazards Earth Syst Sci. 2005;5(4): 477-94. doi:10.5194/nhess-5-477-2005.

Spence RJ, Kelman I, Brown A, Toyos G, Purser D, Baxter P. Residential building and occupant vulnerability to pyroclastic density currents in explosive eruptions. Nat Hazards Earth Syst Sci. 2007;7(2):219-30. doi:10.5194/nhess-7-219-2007.

Statistics New Zealand. Regional gross domestic product: year ended march 2013. 2013. http://www.stats.govt.nz/browse_for_stats/economic_indicators/ NationalAccounts/RegionalGDP_MRYeMar13.aspx. Accessed 4 Dec 2015.

Statistics New Zealand. Subnational population estimates (RC, AU), by age and sex, at 30 June 1996, 2001, 2006-16 (2017 boundaries). 2015. http://nzdotstat.stats.govt.nz/wbos/Index.aspx?DataSetCode= TABLECODE7501. Accessed 24 Oct 2016. 
Stewart C, Johnston DM, Leonard GS, Horwell CJ, Thordarson T, Cronin SJ. Contamination of water supplies by volcanic ashfall: a literature review and simple impact modelling. J Volcanol Geotherm Res. 2006;158(3-4):296-306. doi:10.1016/j.jvolgeores.2006.07.002.

Sutherland R, Kidwell-Ross R. 10 tips for ensuring a more environmental and cost-effective street sweeping program. 2010. http://www.worldsweeper. com/Street/BestPractices/Sutherland10Tips10.10.html. Access 1 Sept 2014.

Sword-Daniels V, Wilson TM, Sargeant S, Rossetto T, Twigg J, Johnston DM, Loughlin SC, Cole PD. Consequences of long-term volcanic activity for essential services in Montserrat: challenges, adaptations and resilience. In: Wadge G, Robertson REA, Voight B, editors. The Eruption of Soufriere Hills Volcano, Montserrat from 2000 to 2010. London: Geological Society of London Memoirs; 2014. p. 471-88. doi:10.1144/m39.26.

Tanikawa H, Managi S, Lwin CM. Estimates of lost material stock of buildings and roads due to the great East Japan earthquake and tsunami. J Ind Ecol. 2014; 18:421-31. doi:10.1111/jiec.12126.

United Nations Office for the Coordination of Humanitarian Affairs. Disaster Waste Guidelines. Switzerland: UNEP/OCHA Environmental Unit; 2011.

United States Department of Labor. CPI detailed report: data for december 2015. 2016. http://www.bls.gov/cpi/cpid1512.pdf. Accessed 1 Mar 2016.

United States Environmental Protection Agency. Planning for natural disaster debris, office of solid waste and emergency and response/office of solid waste, United States. 2008.

Villemure M, Wilson TM, Bristow D, Gallagher M, Giovinazzi S, Brown C. Liquefaction ejecta clean-up in Christchurch during the 2010-2011 earthquake sequence, 2012 NZSEE Conference. Christchurch: 2012.

Wardman J, Stewart C, Wilson TM. Impact assessment of the May 2010 eruption of Pacaya volcano, Guatemala. GNS Science Report 2012/09. 2012.

Wilson TM, Cole JW, Stewart C, Cronin SJ, Johnston DM. Ash storms: Impacts of wind-remobilised volcanic ash on rural communities and agriculture following the 1991 Hudson eruption, southern Patagonia, Chile. Bull Volcanol. 2011a;73(3):223-39. doi:10.1007/s00445-010-0396-1.

Wilson TM, Stewart C, Sword-Daniels V, Leonard GS, Johnston DM, Cole JW. Wardman J, Wilson G, Barnard ST. Volcanic ash impacts on critical infrastructure. Phys Chem Earth. 2012;45-46:5-23. doi:10.1016/j.pce.2011.06.006.

Wilson TM, Stewart C, Bickerton H, Baxter P, Outes V, Villarosa G, Rovere E. Impacts of the June 2011 Puyehue-Cordón Caulle volcanic complex eruption on urban infrastructure, agriculture and public health. GNS Science Report 2012/20. 2013.

Wilson G, Wilson TW, Deligne NI, Cole JW. Volcanic hazard impacts to critical infrastructure: a review. J Volcanol Geotherm Res. 2014;286:148-82. doi:10. 1016/j.jvolgeores.2014.08.030.

Young S, Balluz L, Malilay J. Natural and technologic hazardous material releases during and after natural disasters: a review. Sci Total Environ. 2004;322(1-3): 3-20. doi:10.1016/50048-9697(03)00446-7.

\section{Submit your manuscript to a SpringerOpen ${ }^{\circ}$ journal and benefit from:}

- Convenient online submission

- Rigorous peer review

- Immediate publication on acceptance

- Open access: articles freely available online

- High visibility within the field

- Retaining the copyright to your article

Submit your next manuscript at $\boldsymbol{s p r i n g e r o p e n . c o m ~}$ 